Article

\title{
Two-Dimensional Modeling of the Oxidative Coupling of Methane in a Fixed Bed Reactor: A Comparison among Different Catalysts
}

\author{
Salamah Manundawee ${ }^{1}$, Amornchai Arpornwichanop ${ }^{2}$, Suttichai Assabumrungrat ${ }^{2}$, \\ and Wisitsree Wiyaratn ${ }^{1, *}$ \\ 1 Faculty of Industrial Education and Technology, King Mongkut's University of Technology Thonburi, \\ Bangkok 10140, Thailand \\ 2 Department of Chemical Engineering, Faculty of Engineering, Chulalongkorn University, Bangkok \\ 10330, Thailand
}

*E-mail: wisitsree.wiy@kmutt.ac.th (Corresponding author)

\begin{abstract}
A proposed two-dimensional model of the oxidative coupling of methane $(\mathrm{OCM})$ to $\mathrm{C}_{2}$ hydrocarbons (e.g., $\mathrm{C}_{2} \mathrm{H}_{4}$ and $\mathrm{C}_{2} \mathrm{H}_{6}$ ) in a fixed bed reactor operated under isothermal and non-isothermal conditions is described which can provide more accurate predictions of experimental data than the simplified one-dimensional model. The model includes a set of partial differential equations of the continuity, mass transfer and energy balance equations. The performance of the OCM using different catalysts was assessed in terms of $\mathrm{CH}_{4}$ conversion, $\mathrm{C}_{2}$ selectivity and $\mathrm{C}_{2}$ yield with respect to key operating parameters, such as feed temperature (973-1173 K), $\mathrm{CH}_{4} / \mathrm{O}_{2}$ ratio (3.4-7.5) and gas hour space velocity (GHSV) (18000-30000 $\left.\mathrm{h}^{-1}\right)$. The simulation results indicated that the Na-W$\mathrm{Mn} / \mathrm{SiO}_{2}$ catalyst exhibits the best performance among all of the catalysts. The $\mathrm{C}_{2}$ yield were $20.16 \%$ and $20.00 \%$ for non-isothermal and isothermal modes respectively which the OCM reactor is operated at a $\mathrm{CH}_{4} / \mathrm{O}_{2}$ ratio of 3.4, a feed temperature of $1073 \mathrm{~K}$ and a GHSV of $9720 \mathrm{~h}^{-1}$. An increase in the operating temperature increases the $\mathrm{CH}_{4}$ conversion but decreases the $\mathrm{C}_{2}$ selectivity. However, the effects of the $\mathrm{CH}_{4} / \mathrm{O}_{2}$ ratio and the GHSV exhibit an opposite trend to that of the operating temperature.
\end{abstract}

Keywords: Oxidative coupling of methane (OCM), fixed bed reactor, two-dimensional model, gas hour space velocity (GHSV).

ENGINEERING JOURNAL Volume 21 Issue 3

Received 24 June 2016

Accepted 6 December 2016

Published 15 June 2017

Online at http://www.engj.org/

DOI:10.4186/ej.2017.21.3.77 


\section{Introduction}

Natural gas consists primarily of methane and is a raw material for a number of synthetic products [1]. One of many processes for natural gas utilization is oxidative coupling of methane (OCM); this process can directly convert methane into precious $\mathrm{C}_{2}$ hydrocarbons. Works on the OCM reaction have been reported since the pioneering work of Keller and Bhasin in 1982. However, it is still a great challenge to improve on obtaining higher conversion of methane and ethylene, and high $\mathrm{C}_{2}$ hydrocarbons selectivity in the production process [2].

In OCM process, several reactions occur simultaneously including homogeneous gas phase reactions and heterogeneous catalytic reactions, parallel and consecutive reaction with very complex reaction kinetics. Numerous kinetic reaction models have been presented to describe the performance of the OCM process over a large number of catalysts [3-7]. Several catalysts for OCM reaction were found to be effective in heterogeneous-homogeneous complex process [8] . Parameters of metal oxides, such as basicity, band gap, and electrical oxidative coupling of methane conductivity were some of the important parameters in affecting the catalyst performance. However, $\mathrm{Li} / \mathrm{MgO}, \mathrm{La}_{2} \mathrm{O}_{3} / \mathrm{CaO}$ and $\mathrm{Na}-\mathrm{W}-\mathrm{Mn} / \mathrm{SiO}_{2}$ were three of the most popular catalysts presented in the literature involving the studies of the OCM process because of their high performance [9-13]. $\mathrm{Li} / \mathrm{MgO}$ is one of the most commonly studied OCM catalyst system, particularly to show that higher $\mathrm{C}_{2}$ yields $(>70 \%)$ are attained in the dense oxide membrane reactor than in conventional packed-bed reactors and it showed high catalytic activity in the low temperature range [14-16]. In additional, $\mathrm{La}_{2} \mathrm{O}_{3} / \mathrm{CaO}$ demonstrated a promising result with $42 \%$ methane conversion and yield up to $20 \%$ [17]. Their kinetic reaction for OCM has been a strong interest in $\mathrm{Na}-\mathrm{W}-\mathrm{Mn} / \mathrm{SiO}_{2}$ and is thus extensively studied by several researchers. Their experimental results suggested this catalyst had appealing prospects in commercial application [18].

There are many types of reactors such as moving bed chromatographic reactor, membrane reactor, fluidized-bed reactor, catalytic jet-stirred reactor, and fixed bed reactor, have been reported. The applications of membrane reactor combining the separation and reaction in one unit to control oxygen concentration along the reactor were promising in enhancing $\mathrm{CH}_{4}$ conversion, yield and $\mathrm{C}_{2}$ selectivity for OCM process. The performances of catalytic membrane reactor (CMR), catalyst packed bed membrane reactor (PBMR), and packed bed reactor (PBR) were compared at optimum condition and found that $\mathrm{CMR}$ performed best among three reactors with $\mathrm{CH}_{4}$ conversion by Bhatia and his co-workers [19]. Wang and co-workers showed the remarkable study that the improvement of $\mathrm{C}_{2}$ selectivity was observed when catalyst was packed in the membrane tube [20]. Fixed bed reactor is investigated in the most studied due to technically feasible and economic. Using mathematical model in fixed bed reactor study on OCM process was the easiest to design, scale up, and could be analyzed. In addition, OCM is an extremely exothermic reaction, and hot spots always occur in the catalyst. Heat removal was therefore essential for practical operation, and reactors were likely to be operated under non-isothermal condition [21]. The design of the fixed bed reactor using a two-dimensional mathematical model considering both axial- and radial-directions is more complex than that of a one-dimensional study considering only the axial axis. The two-dimensional model is more realistic and provides better prediction accuracy than the one-dimensional model. The need for the two-dimensional model becomes essential when a reactor with a large diameter is operated because the effect of radial dispersion becomes more pronounced. In the reactor design, it is important to determine a location where the hot spot is severe so that the operational problems, such as catalyst sintering, can be avoided and a suitable operating condition can be selected.

Therefore, in this study, two-dimensional mathematical modelling of the oxidative coupling of methane (OCM) to $\mathrm{C}_{2}$ hydrocarbons $\left(\mathrm{C}_{2} \mathrm{H}_{4}\right.$ and $\left.\mathrm{C}_{2} \mathrm{H}_{6}\right)$ in a fixed bed operated under isothermal and non-isothermal conditions is investigated using the COMSOL ${ }^{\circledR}$ Multiphysics Program. Fixed bed reactors are modelled using the available information on the reaction kinetics of three different catalysts. The simulations are aimed at finding a suitable catalyst and determining the performance of the OCM process using a twodimensional mathematical model. 


\section{Simulation}

\subsection{Kinetic Model}

Numerous kinetic reaction models have been presented to describe the performance of the OCM process over several catalysts. $\mathrm{Li} / \mathrm{MgO}, \mathrm{La}_{2} \mathrm{O}_{3} / \mathrm{CaO}$ and $\mathrm{Na}-\mathrm{W}-\mathrm{Mn} / \mathrm{SiO}_{2}$ are three of the most studied catalysts in the literature related to the OCM process. $\mathrm{Li} / \mathrm{MgO}$ exhibits high catalytic activity in the low temperature range, $\mathrm{La}_{2} \mathrm{O}_{3} / \mathrm{CaO}$ was one of the most common catalysts used in OCM models and $\mathrm{Na}-\mathrm{W}-\mathrm{Mn} / \mathrm{SiO}_{2}$ was one of the most studied three-component catalyst. In the model, the kinetic mechanism and kinetic equations considered in this work were proposed by Wang and Lin [3] over a Li/ $\mathrm{MgO}$ catalyst, Stansch et al. [4] over a $\mathrm{La}_{2} \mathrm{O}_{3} / \mathrm{CaO}$ catalyst and Danespayeh et al. [18] over a $\mathrm{Na}-\mathrm{W}-\mathrm{Mn} / \mathrm{SiO}_{2}$ catalyst. The stoichiometric equation and reaction rate of each of the proposed models are presented in Table 1.

\subsection{Reactor Model}

The transport phenomena were coupled with the reaction kinetics to develop a reactor model. The twodimensional flow field in a fixed bed reactor was coupled with the mass and heat transport for the simulation performance of the OCM process, as well as the velocity, concentration and temperature profiles.

\subsubsection{Geometry and boundary condition}

The reactor geometry considered was a $2 \mathrm{D}$ cylindrical one, and the flow enters the computational domain at a known velocity, composition and temperature. At the outlet, it was assumed that the convective part of the mass and heat transport vector was dominating. At the tube wall, a heat transfer was defined in nonisothermal mode, which defined the wall insulation in adiabatic operation, and the heat flux was removed from the wall in constant-wall temperature operation. The geometry of the fixed bed reactor is presented in Figure 1, which shows the scheme of the FBR. Methane and air were mixed and co-fed to an impermeable tubular reactor; the inner tube was filled with a bed of catalyst.

The reactor model was based on the following basic assumptions: two-dimensional mathematical model, steady-state operation and ideal gas behaviour. In addition, diffusivity in the catalyst bed was assumed to be via the Knudsen mechanism.

\subsubsection{Governing equations}

Mass balance: the mass balance for each of the eight components can be written as

$$
\left(\frac{\partial^{2} C_{i}}{\partial r^{2}}+\frac{1}{2} \frac{\partial C_{i}}{\partial r}\right)+D_{i} \frac{\partial^{2} C_{i}}{\partial z^{2}}-u \frac{\partial C_{i}}{\partial z}+\rho_{B} r_{i}=0
$$

The rate of production was calculated for each component from the stoichiometry of the reactions.

Energy balance: the energy balance for the reactor can be written as follows.

$$
\lambda\left(\frac{\partial^{2} T}{\partial r^{2}}+\frac{1}{2} \frac{\partial T}{\partial r}\right)+\frac{\partial^{2} T}{\partial z^{2}}-u \rho_{f} C_{p} \frac{\partial T}{\partial z}+Q=0
$$

The heat source in Eq. (2), including heat of reaction and heat flux, were computed by

$$
Q=\sum_{i=1}^{n} \Delta H_{r x n} r_{i}+U\left(T-T_{e x}\right)
$$

Momentum balance: the momentum balance for reactor describes the flow in the porous media. The equation extends Darcy's law combination with the continuity equation:

$$
\nabla\left(-\eta\left(\nabla u+(\nabla u)^{T}\right)\right)+\frac{k}{\eta} u=0
$$


Table 1. Stoichiometric equation and reaction rate of proposed models.

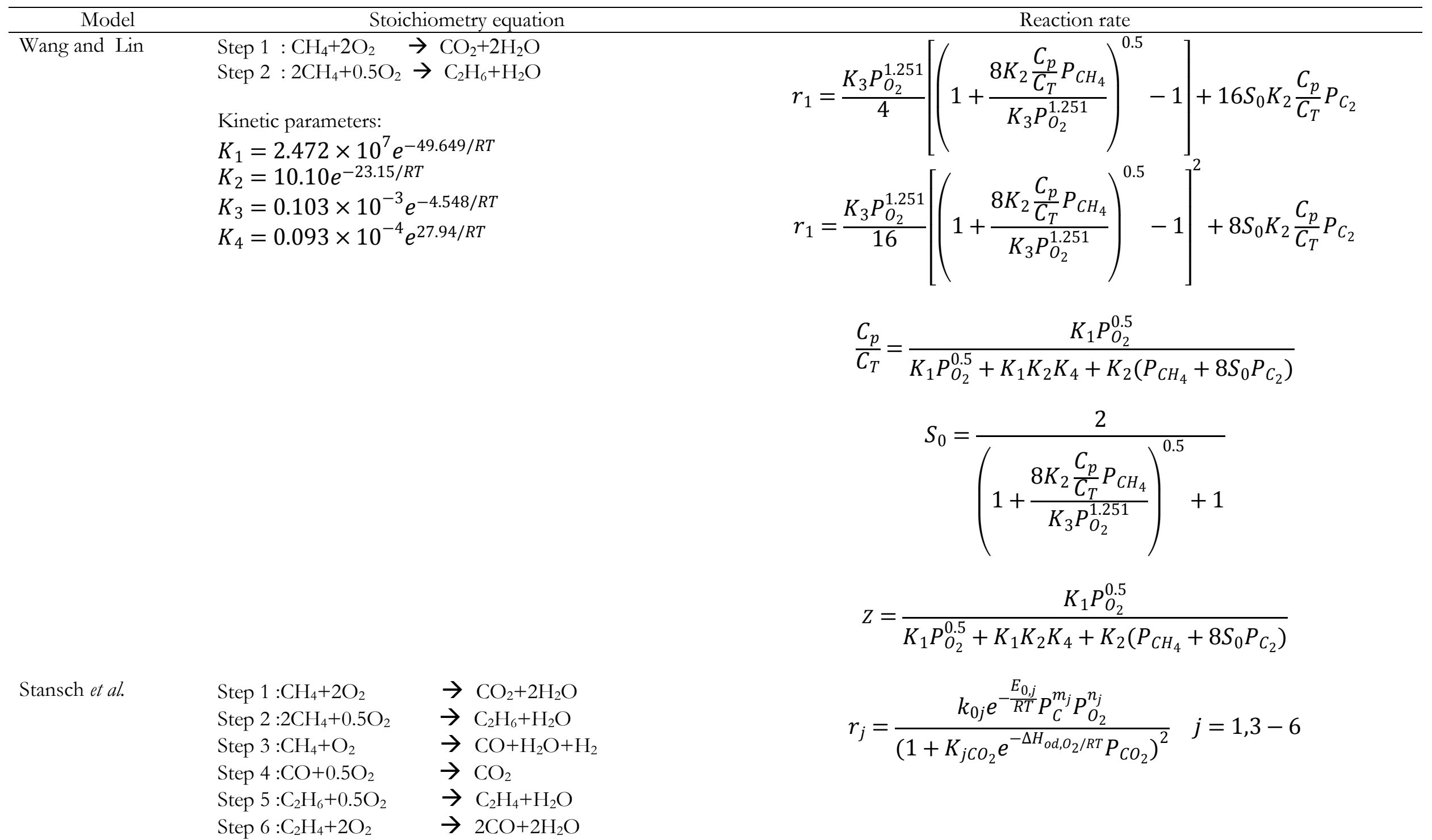




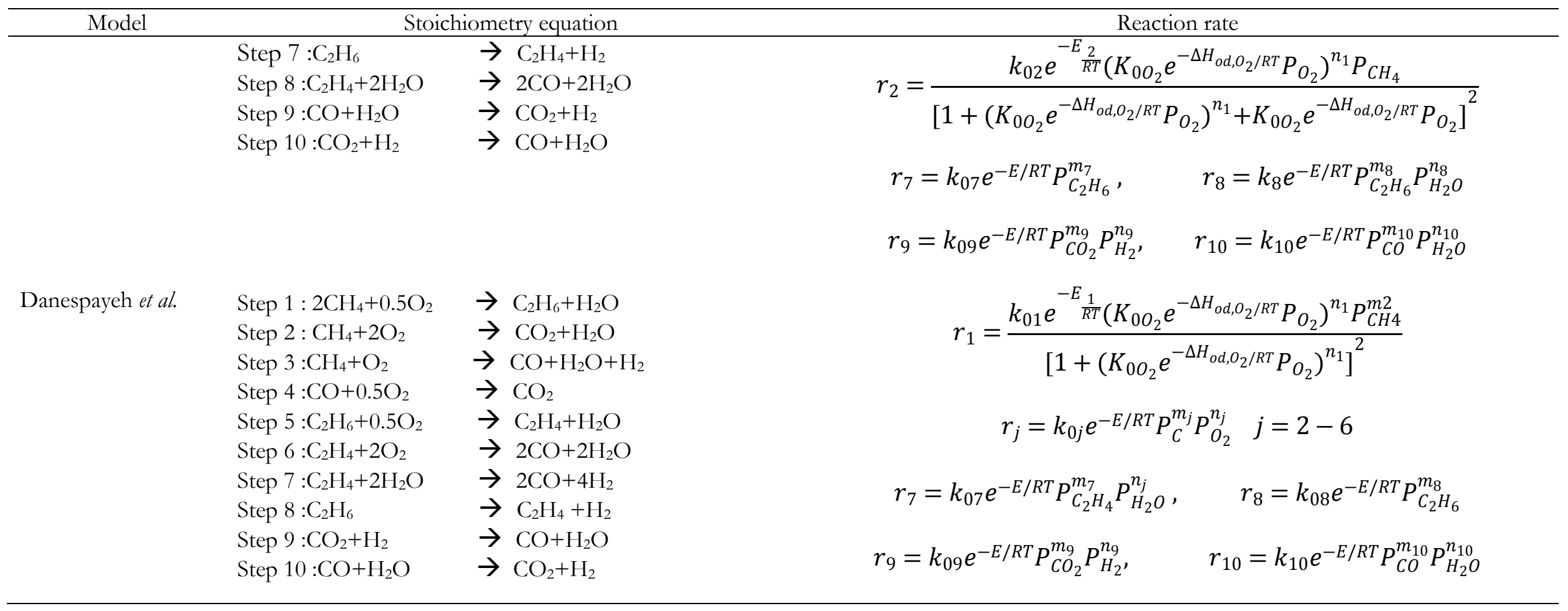


The performance of the reactor was evaluated by the conversion of reactants as well as the selectivity and the yield of the products. The conversion was defined as the fraction of the reactant that was reacted to the amount of reactant fed. For example, the conversion of methane was

$$
\mathrm{CH}_{4} \text { conversion } \%=\frac{F_{\mathrm{CH}_{4}}^{0}-F_{C_{4}}}{F_{C H_{4}}^{0}} \times 100
$$

and the $\mathrm{C}_{2}$ selectivity was defined as the $\mathrm{C}_{2}$ product formed per reactant consumed.

$$
\mathrm{C}_{2} \text { selectivity } \%=\frac{2 \times\left(F_{\mathrm{C} 2 \mathrm{H} 4}+F_{\mathrm{C} 2 \mathrm{H} 6}\right)}{\left(2\left(F_{\mathrm{C} 2 \mathrm{H} 4}+F_{\mathrm{C} 2 \mathrm{H} 6}\right)+F_{\mathrm{CO}}+F_{\mathrm{CO} 2}\right)} \times 100
$$

Moreover, the $\mathrm{CO}_{\mathrm{x}}$ selectivity was defined as the $\mathrm{CO}_{\mathrm{x}}$ byproduct formed per reactant consumed.

$$
\mathrm{CO}_{\mathrm{x}} \text { selectivity } \%=\frac{F_{\mathrm{CO}}+F_{\mathrm{CO} 2}}{\left(2\left(F_{\mathrm{C} 2 \mathrm{H} 4}+F_{\mathrm{C} 2 \mathrm{H} 6}\right)+F_{\mathrm{CO}}+F_{\mathrm{CO} 2}\right)} \times 100
$$

The yield referred to the specific product formed per reactant fed.

$$
\mathrm{C}_{2} \text { yield } \%=\frac{2 \times\left(\mathrm{F}_{\mathrm{C} 2 \mathrm{H} 4}+\mathrm{F}_{\mathrm{C} 2 \mathrm{H} 6}\right)}{\mathrm{F}_{\mathrm{CH}}^{0}} \times 100
$$

In addition, in a fixed bed reactor, the effect of operating variables under three operating modes, i.e., isothermal, adiabatic, and non-isothermal condition, were considered.

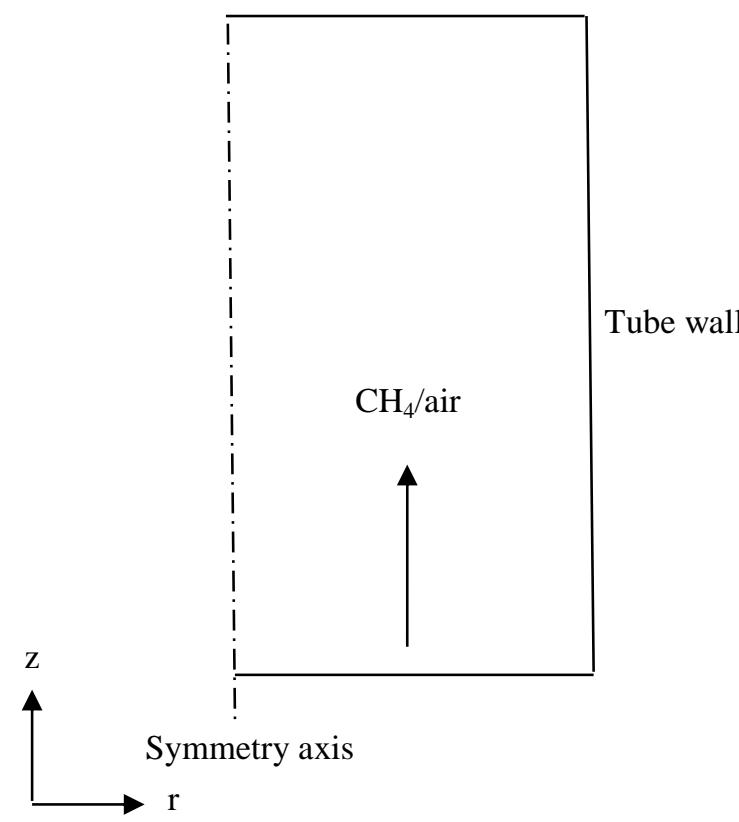

Fig. 1. Geometry of fixed bed reactor.

\subsection{Numerical Approach}

The finite element method was proposed to formulate the PDE problem. In the developed finite element model, the reactor was solved with quadratic finite element basis functions using the commercial finite element simulation environment COMSOL. The software runs the finite element analysis together with meshing, which involves a partition of the geometry model into small units of simple shapes, and error control using a variety of numerical solvers. Three application modes were required to model the heat transfer by conductive and convective processes. Mass transfer by convective processes and diffusion was 
used to simulate the concentration and transport of eight species of interest. The Brinkman equation was applied to describe the fluid flow.

\section{Results and Discussion}

The simulations were performed for OCM in a fixed bed reactor. The conditions used in the simulation are summarized in Table 2, and the catalyst properties are presented in Table 3.

Table 2. Reactor dimension and conditions.

\begin{tabular}{cc}
\hline Condition & Dimension \\
\hline Fixed bed reactor & 0.2 \\
Length of catalyst bed $(\mathrm{m})$ & 0.018 \\
Diameter $(\mathrm{m})$ & $993-1173$ \\
Temperature $(\mathrm{K})$ & 101.325 \\
Pressure $(\mathrm{kPa})$ & $3.4-7.5$ \\
$\mathrm{CH}_{4} / \mathrm{O}_{2}$ ratio & $18000-30000$ \\
$\mathrm{GHSV}\left(\mathrm{h}^{-1}\right)$ & \\
\hline
\end{tabular}

Table 3. Catalyst properties.

\begin{tabular}{lccc}
\hline \multicolumn{1}{c}{ Property } & \multicolumn{3}{c}{ catalyst } \\
\cline { 2 - 4 } & $\mathrm{Li} / \mathrm{MgO}$ & $\mathrm{La}_{2} \mathrm{O}_{3} / \mathrm{CaO}$ & $\mathrm{Na}-\mathrm{W}-\mathrm{Mn} / \mathrm{SiO}_{2}$ \\
Average pore radius (m) & 0.0005 & 0.01 & 0.00008 \\
Porosity (-) & 0.34 & 0.6 & 0.6 \\
Totousity (-) & 2.153 & 3 & 1.089 \\
Thermal conductivity (W/m K) & 10.3 & 1 & 1.35 \\
\hline
\end{tabular}

\subsection{Model Validation}

The validation of the kinetic model (for $\mathrm{Li} / \mathrm{MgO}, \mathrm{La}_{2} \mathrm{O}_{3} / \mathrm{CaO}$ and $\mathrm{Na}-\mathrm{W}-\mathrm{Mn} / \mathrm{SiO}_{2}$ catalyst) was performed first to ensure that the mathematical models could well predict the OCM performances. The model used was the two-dimensional plug flow model.

The validity of the $\mathrm{Li} / \mathrm{MgO}$ catalyst using the kinetic rate expression reported by Wang and Lin [3] was assessed by comparing our simulation results with the simulation data from the literature [13] in the fixed bed reactor. Figure 2(a) shows yield of the $\mathrm{C}_{2}$ products versus the run numbers under the conditions in the literature, which are presented in Table 4(a). Figure 2(b) shows the validation results of the $\mathrm{La}_{2} \mathrm{O}_{3} / \mathrm{CaO}$ catalyst by comparing our simulation results with the simulation data reported by Tye et al. [12] in terms of the $\mathrm{C}_{2}$ yield versus the run numbers under the conditions of the literature, which are presented in Table 4 (b). Figure 2(c) shows the comparison between our results and the results reported in the literature by Daneshpayeh et al. [18] for a Na-W-Mn/SiO 2 catalyst, which provided conversion of $\mathrm{CH}_{4}$ in a range of $16.5-19 \mathrm{~kg} \mathrm{~m}^{3} / \mathrm{s}$ at a temperature of $1048 \mathrm{~K}$. Our simulation results are found to agree well with simulation data from the literature. 


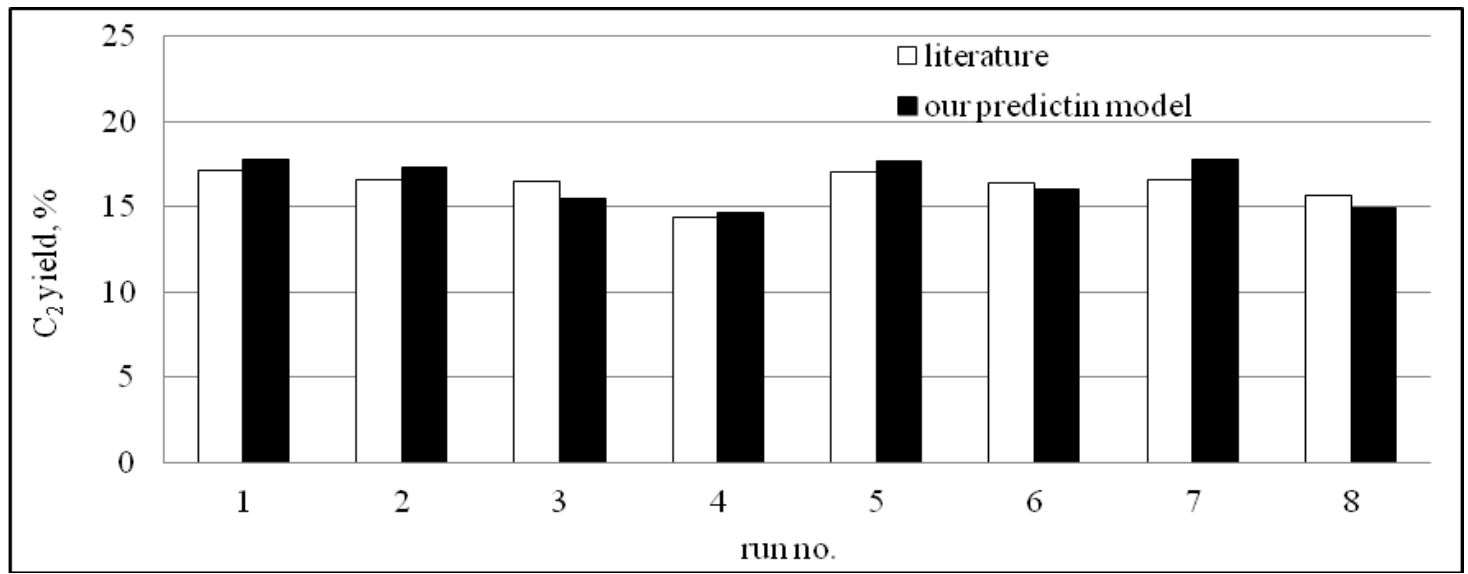

(a)

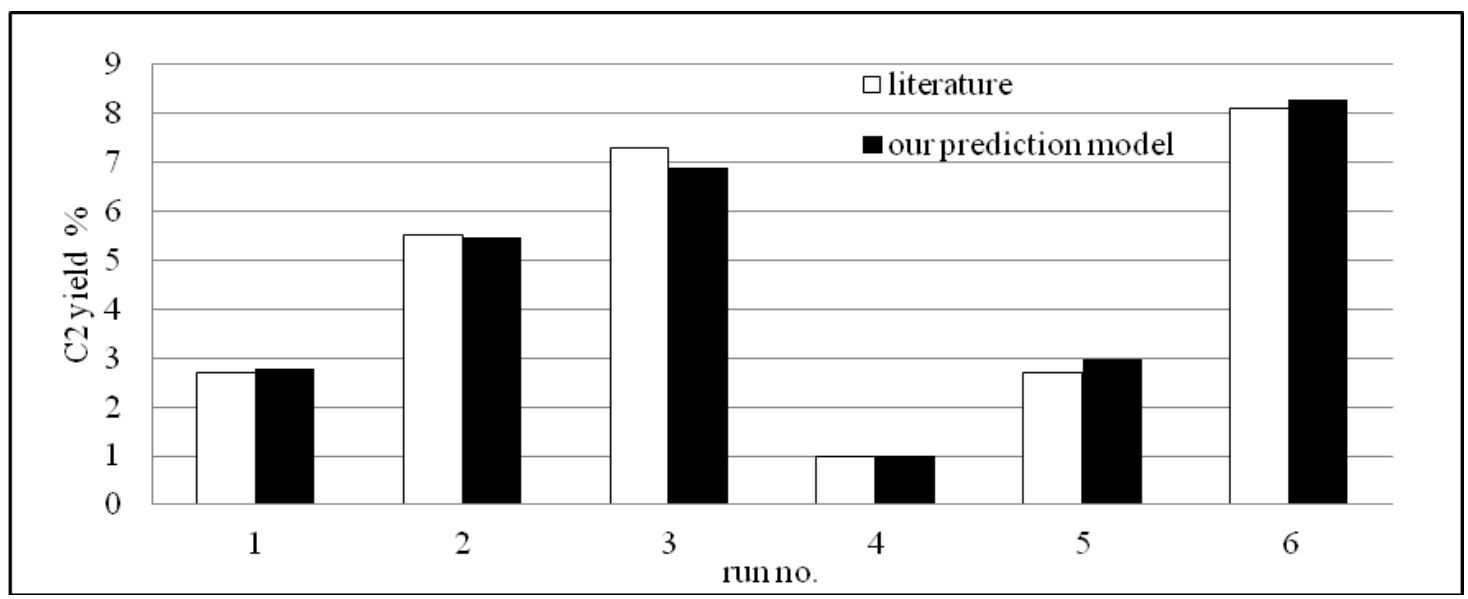

(b)

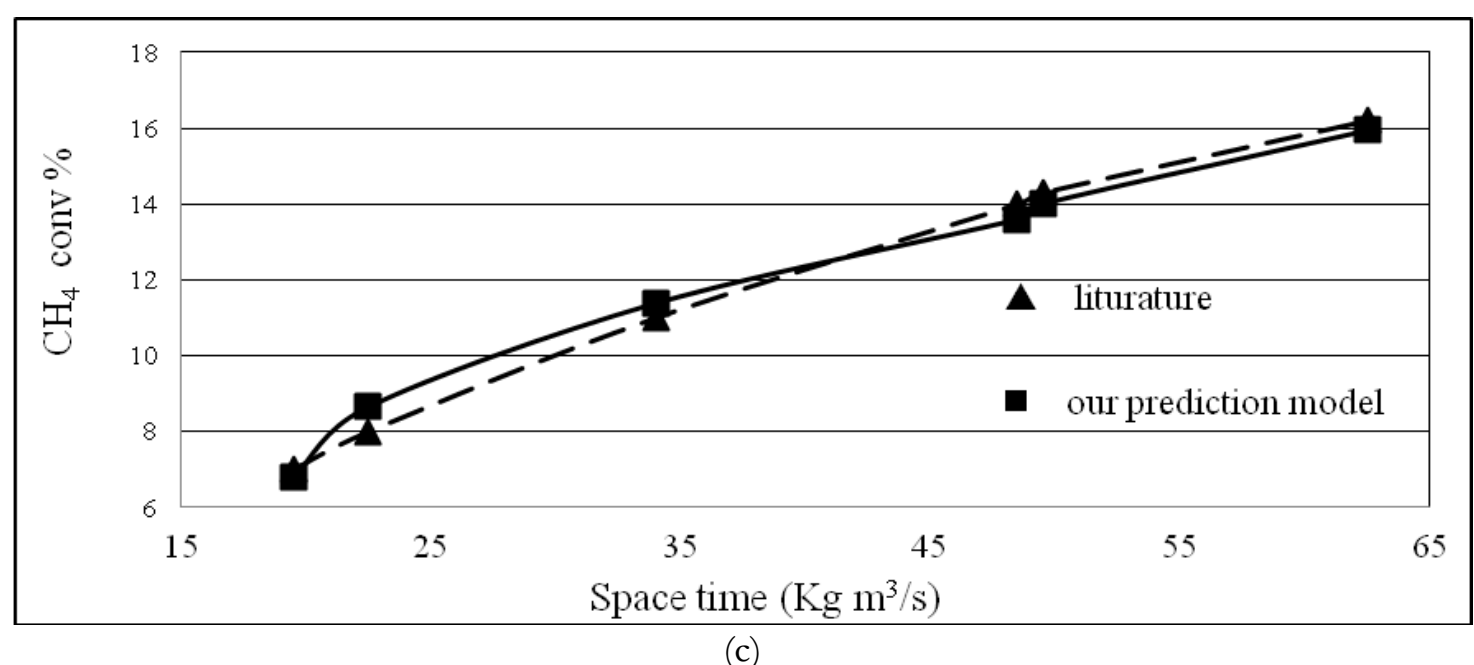

Fig. 2. Comparison between literature and our prediction model over $\mathrm{Li} / \mathrm{MgO}$ (a.), $\mathrm{La}_{2} \mathrm{O}_{3} / \mathrm{CaO}$ (b.) and $\mathrm{Na}-\mathrm{W}-\mathrm{Mn} / \mathrm{SiO}_{2}$ (c.) catalysts. 
Table 4. Condition for different run number.

\begin{tabular}{|c|c|c|c|c|c|c|c|c|c|}
\hline \multirow{2}{*}{ Model } & \multirow{2}{*}{ Condition } & \multicolumn{8}{|c|}{ Run no. } \\
\hline & & 1 & 2 & 3 & 4 & 5 & 6 & 7 & 8 \\
\hline \multirow{5}{*}{$\begin{array}{l}\text { (a) Kao et al. } \\
\text { (1997) }\end{array}$} & Temperature(K) & \multicolumn{8}{|c|}{993} \\
\hline & 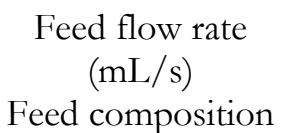 & \multicolumn{8}{|c|}{0.83} \\
\hline & - $\mathrm{He}$ & 0.8921 & 0.8566 & 0.7882 & 0.3347 & 0.8842 & 0.8763 & 0.8447 & 0.5592 \\
\hline & - $\mathrm{CH}_{4}$ & 0.0724 & 0.1118 & 0.1118 & 0.3987 & 0.0776 & 0.0763 & 0.1171 & 0.2868 \\
\hline & $-\mathrm{O}_{2}$ & 0.0355 & 0.0316 & 0.1000 & 0.2066 & 0.0382 & 0.0474 & 0.0382 & 0.1540 \\
\hline \multirow{5}{*}{$\begin{array}{l}\text { (b) Tye } e t \text { al. } \\
\text { (2002) }\end{array}$} & Temperature (K) & 1023 & 1073 & 1103 & 973 & 1023 & 1103 & & \\
\hline & $\begin{array}{l}\text { Feed flow rate } \\
(\mathrm{mL} / \mathrm{s}) \\
\text { Feed molar ratio }\end{array}$ & \multicolumn{8}{|c|}{4} \\
\hline & $\begin{array}{ll}- & \mathrm{CH}_{4}\end{array}$ & 0.612 & 0.612 & 0.612 & 0.699 & 0.699 & 0.699 & & \\
\hline & $\mathrm{O}_{2}$ & 0.051 & 0.051 & 0.051 & 0.095 & 0.095 & 0.095 & & \\
\hline & $\mathrm{N}_{2}$ & 0.337 & 0.337 & 0.337 & 0.206 & 0.206 & 0.206 & & \\
\hline
\end{tabular}

\subsection{Catalytst Selection}

This section considers the selection of a suitable catalyst among $\mathrm{Li} / \mathrm{MgO}, \mathrm{La}_{2} \mathrm{O}_{3} / \mathrm{CaO}$ and $\mathrm{Na}-\mathrm{W}-\mathrm{Mn} / \mathrm{SiO}_{2}$ catalysts at various conditions, i.e., gas hourly space velocity (GHSV), $\mathrm{CH}_{4} / \mathrm{O}_{2}$ ratio, and temperature. The system was based on a fixed bed reactor under isothermal operation mode. A summary of the operating conditions in this section is presented in Table 5 .

The performance of the OCM reaction was considered in terms of the $\mathrm{CH}_{4}$ conversion and the $\mathrm{C}_{2}$ selectivity. Figure 3 shows the activities of the three catalysts for GHSV in a range of 18000 to $300001 / \mathrm{h}$. The order of the $\mathrm{CH}_{4}$ conversion follows $\mathrm{Na}-\mathrm{W}-\mathrm{Mn} / \mathrm{SiO}_{2}>\mathrm{La}_{2} \mathrm{O}_{3} / \mathrm{CaO}>\mathrm{Li} / \mathrm{MgO}$. The $\mathrm{CH}_{4}$ conversion was decreased with the increase of the GHSV for all catalysts.

Figures 4-8 show the results of the $\mathrm{C}_{2}$ selectivity to $\mathrm{CH}_{4}$ conversion at a position of reactor length (the inlet of the reactor at $\mathrm{CH}_{4}$ conversion was set to zero) under different conditions, which are summarized in Table 5 from all figures; the $\mathrm{CH}_{4}$ conversion was increased and the $\mathrm{C}_{2}$ selectivity was decreased with an increase of the distance from the inlet to the reactor for all catalysts. It was obvious that $\mathrm{CH}_{4}$ conversion for the $\mathrm{Na}-\mathrm{W}-\mathrm{Mn} / \mathrm{SiO}_{2}$ catalyst was higher than those for the $\mathrm{La}_{2} \mathrm{O}_{3} / \mathrm{CaO}$ and $\mathrm{Li} / \mathrm{MgO}$ catalysts. Moreover, the $\mathrm{C}_{2}$ selectivity for the $\mathrm{Na}-\mathrm{W}-\mathrm{Mn} / \mathrm{SiO}_{2}$ catalyst was higher than those for the $\mathrm{Li} / \mathrm{MgO}$ and $\mathrm{La}_{2} \mathrm{O}_{3} / \mathrm{CaO}$ catalysts. The $\mathrm{CO}_{x}$ selectivity for the $\mathrm{La}_{2} \mathrm{O}_{3} / \mathrm{CaO}$ catalyst was higher than those for the $\mathrm{Li} / \mathrm{MgO}$ and $\mathrm{Na}-\mathrm{W}-\mathrm{Mn} / \mathrm{SiO}_{2}$ catalysts at all conditions. In addition, even the $\mathrm{La}_{2} \mathrm{O}_{3} / \mathrm{CaO}$ catalyst provides a $\mathrm{CH}_{4}$ conversion higher than that of the $\mathrm{Li} / \mathrm{MgO}$ catalyst, but the $\mathrm{C}_{2}$ selectivity was lower. The presence of oxygen as a co-feed reactant affected to limited $\mathrm{CH}_{4}$ conversion at different values as a result of consumed oxygen completely in the reaction. The comparison of the OCM performance among the catalysts at various $\mathrm{CH}_{4} / \mathrm{O}_{2}$ ratios is shown in Figs. 4-6. The $\mathrm{CH}_{4}$ conversion was decreased while the $\mathrm{C}_{2}$ selectivity was increased with the increase of the $\mathrm{CH}_{4} / \mathrm{O}_{2}$ ratio for all catalysts. Moreover, the comparison of the OCM performance among the different catalysts at various temperatures is shown in Figs. 6-8. The $\mathrm{CH}_{4}$ conversion increased and the $\mathrm{C}_{2}$ selectivity decreased with an increase of the temperature. Note that at higher temperature, the rate of decrease of the $\mathrm{C}_{2}$ selectivity was greater than that at lower temperature, for example, for the $\mathrm{Li} / \mathrm{MgO}$ catalyst, at $1173 \mathrm{~K}$, the difference of $\mathrm{C}_{2}$ selectivity between the outlets to the inlet was $4.43 \%$ but at $993 \mathrm{~K}$ and $1073 \mathrm{~K}$, the differences were $3.58 \%$ and $3.84 \%$, respectively. The maximum $\mathrm{C}_{2}$ yields for all catalysts at a temperature of $1173 \mathrm{~K}$ and a $\mathrm{CH}_{4} / \mathrm{O}_{2}$ ratio of 3.4 were $30.07 \%, 19.2 \%$ and $20.43 \%$ for $\mathrm{Na}-\mathrm{W}-\mathrm{Mn} / \mathrm{SiO}_{2}, \mathrm{La}_{2} \mathrm{O}_{3} / \mathrm{CaO}$ and $\mathrm{Li} / \mathrm{MgO}$, respectively. The simulation results indicated that the $\mathrm{Na}-\mathrm{W}-\mathrm{Mn} / \mathrm{SiO}_{2}$ catalyst offers the best performance among all of the catalysts under isothermal mode. 
Table 5. Summary of operating condition for catalyst selection study.

\begin{tabular}{cccc}
\hline Figure & \multicolumn{3}{c}{ condition } \\
\cline { 2 - 4 } 3 & $\mathrm{GHSV}(1 / \mathrm{h})$ & Temperature $(\mathrm{K})$ & $\mathrm{CH}_{4} / \mathrm{O}_{2}$ ratio \\
3 & $18000-30000$ & 993 & 3.4 \\
4 & $18000-30000$ & 1173 & 7.5 \\
5 & $18000-30000$ & 1173 & 4.2 \\
6 & $18000-30000$ & 1173 & 3.4 \\
7 & $18000-30000$ & 1073 & 3.4 \\
8 & $18000-30000$ & 993 & 3.4 \\
\hline
\end{tabular}

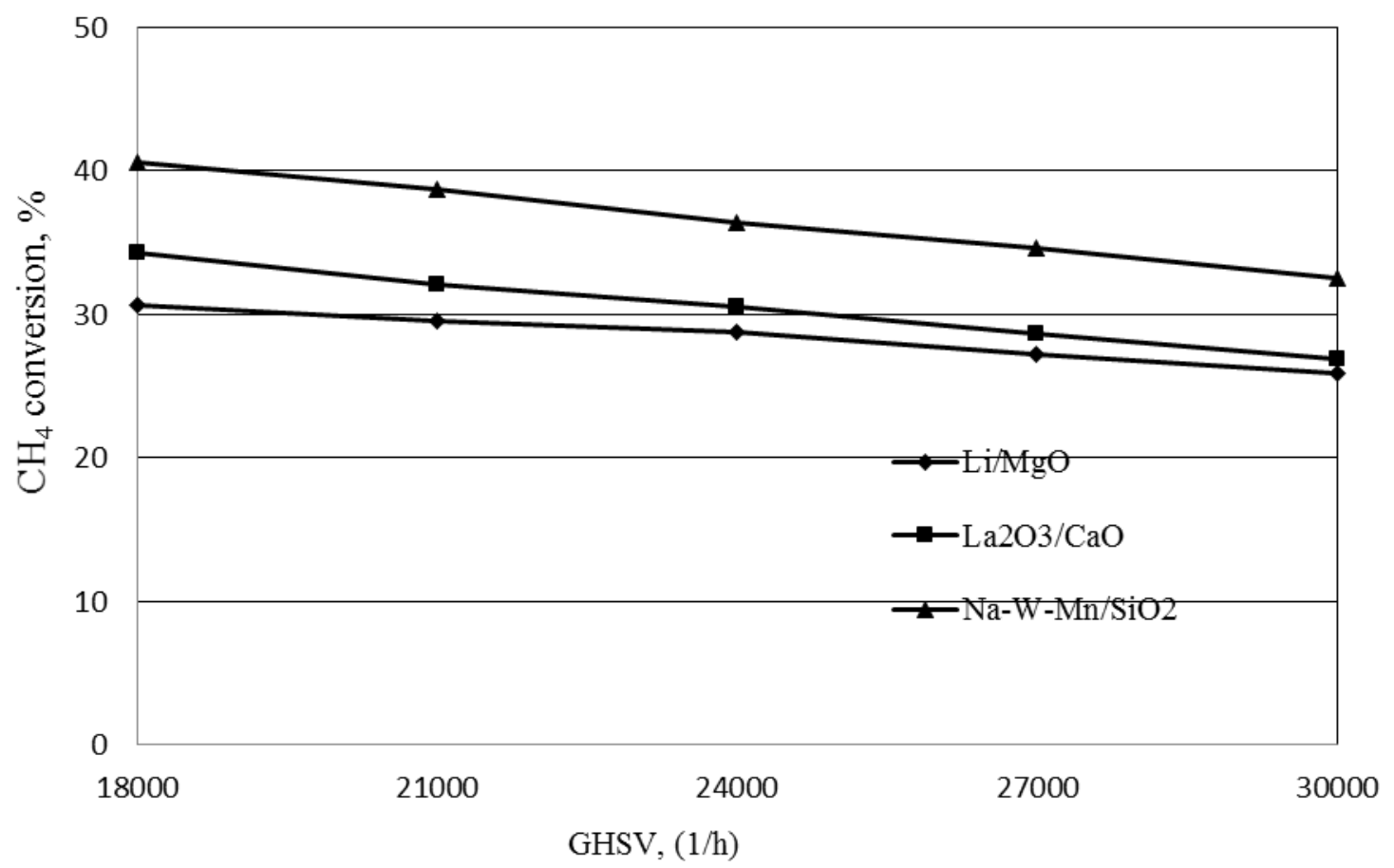

Fig. 3. The activities of $\mathrm{Li} / \mathrm{MgO}, \mathrm{La}_{2} \mathrm{O}_{3} / \mathrm{CaO}$ and $\mathrm{Na}-\mathrm{W}-\mathrm{Mn} / \mathrm{SiO}_{2}$ catalysts in $\mathrm{GHSV}$ range of 18000 to $300001 /$ h. 


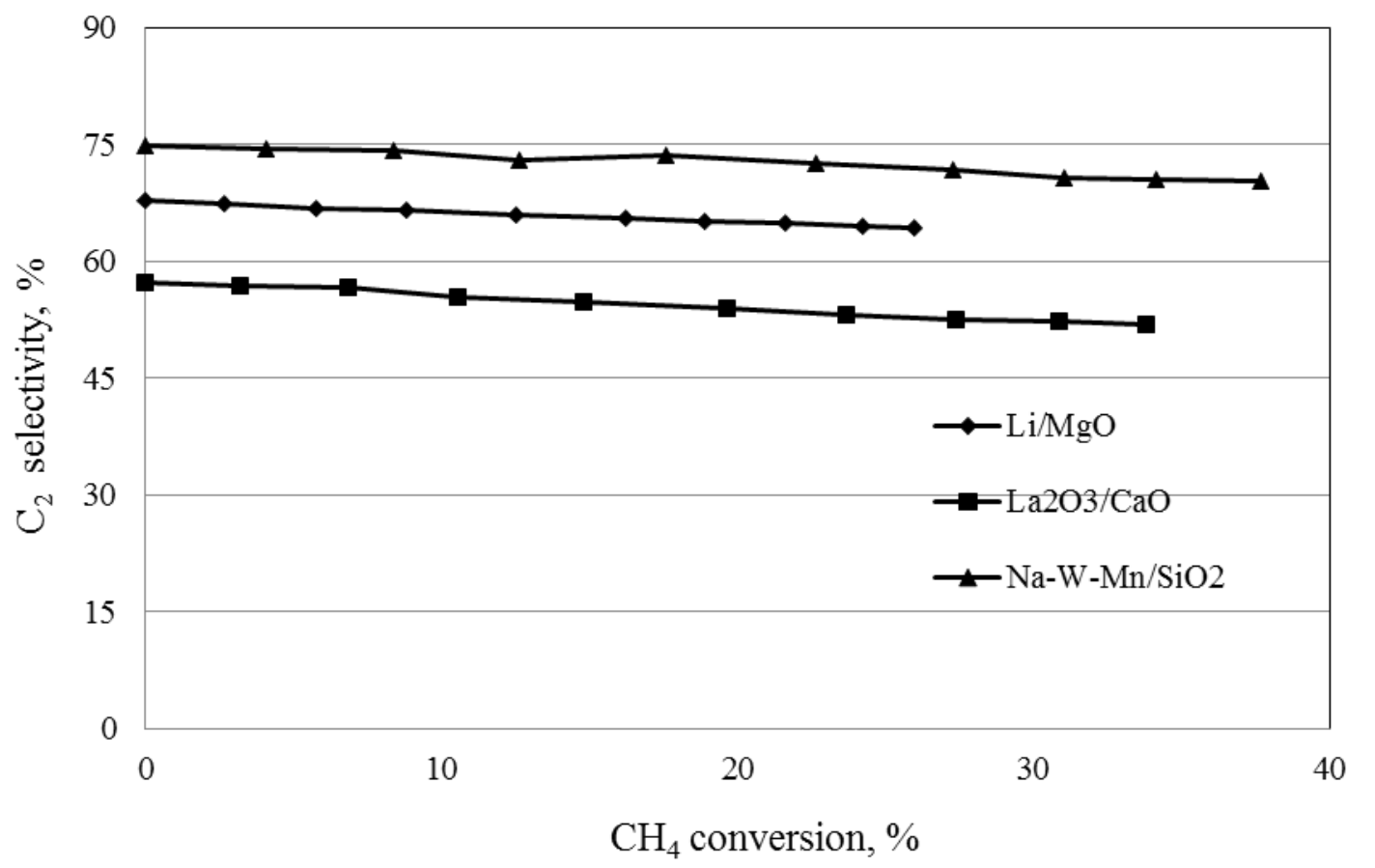

Fig. 4. $\mathrm{CH}_{4}$ conversion VS $\mathrm{C}_{2}$ selectivity $\left(\mathrm{T}=1173 \mathrm{~K}, \mathrm{CH}_{4} / \mathrm{O}_{2}\right.$ ratio $\left.=7.5\right)$.

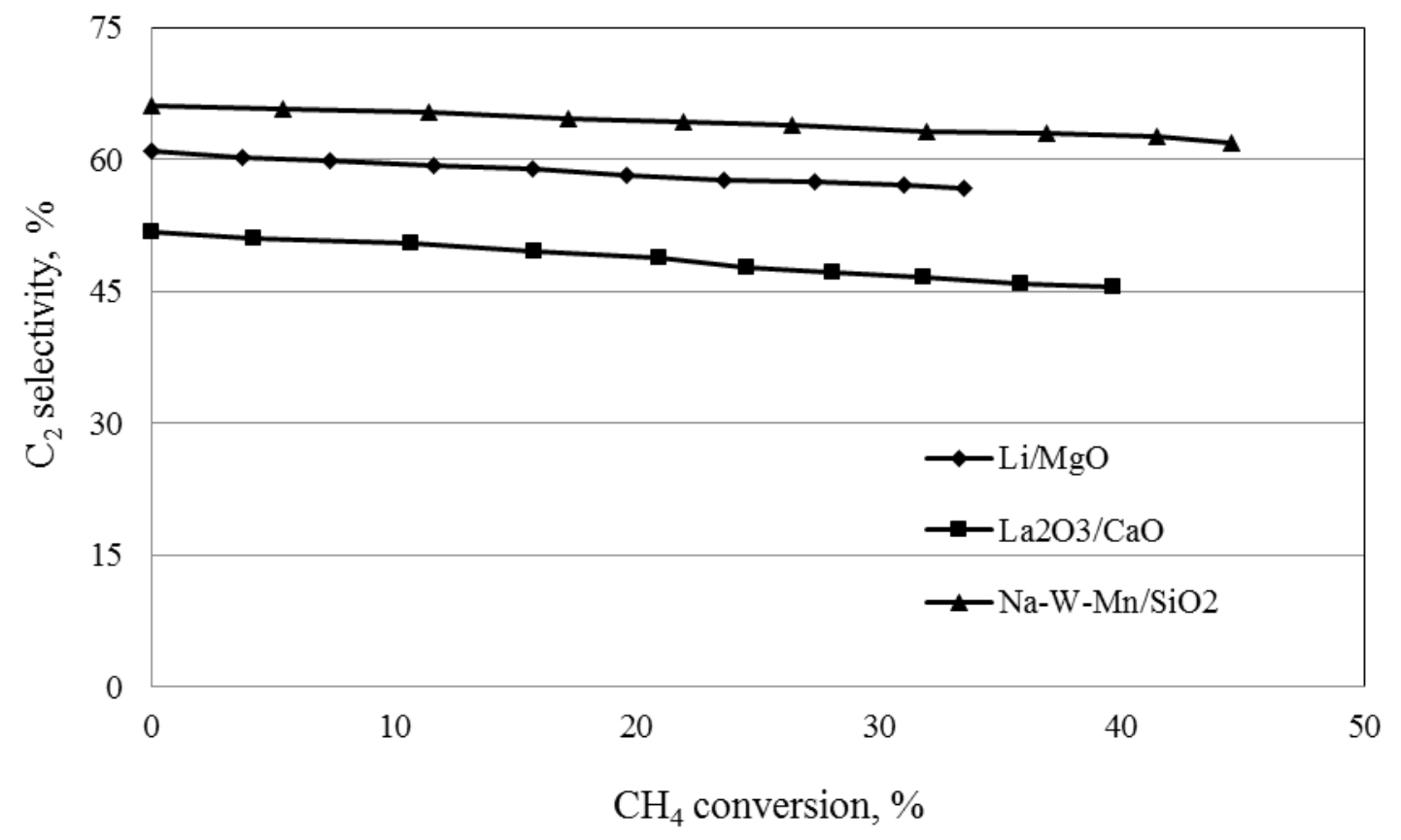

Fig. 5. $\mathrm{CH}_{4}$ conversion VS $\mathrm{C}_{2}$ selectivity $\left(\mathrm{T}=1173 \mathrm{~K}, \mathrm{CH}_{4} / \mathrm{O}_{2}\right.$ ratio $\left.=4.2\right)$. 


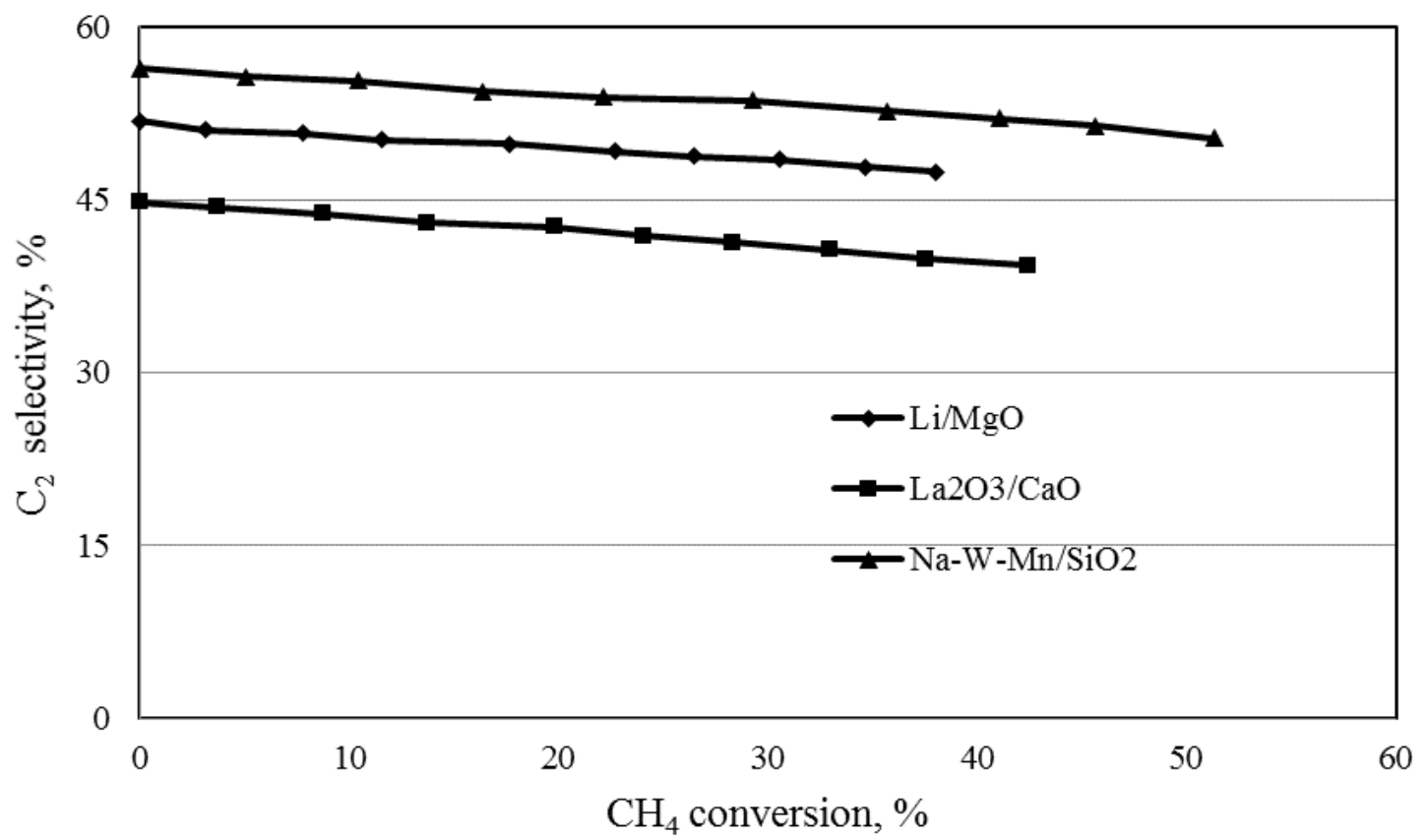

Fig. 6. $\mathrm{CH}_{4}$ conversion VS $\mathrm{C}_{2}$ selectivity $\left(\mathrm{T}=1173 \mathrm{~K}, \mathrm{CH}_{4} / \mathrm{O}_{2}\right.$ ratio $\left.=3.4\right)$.

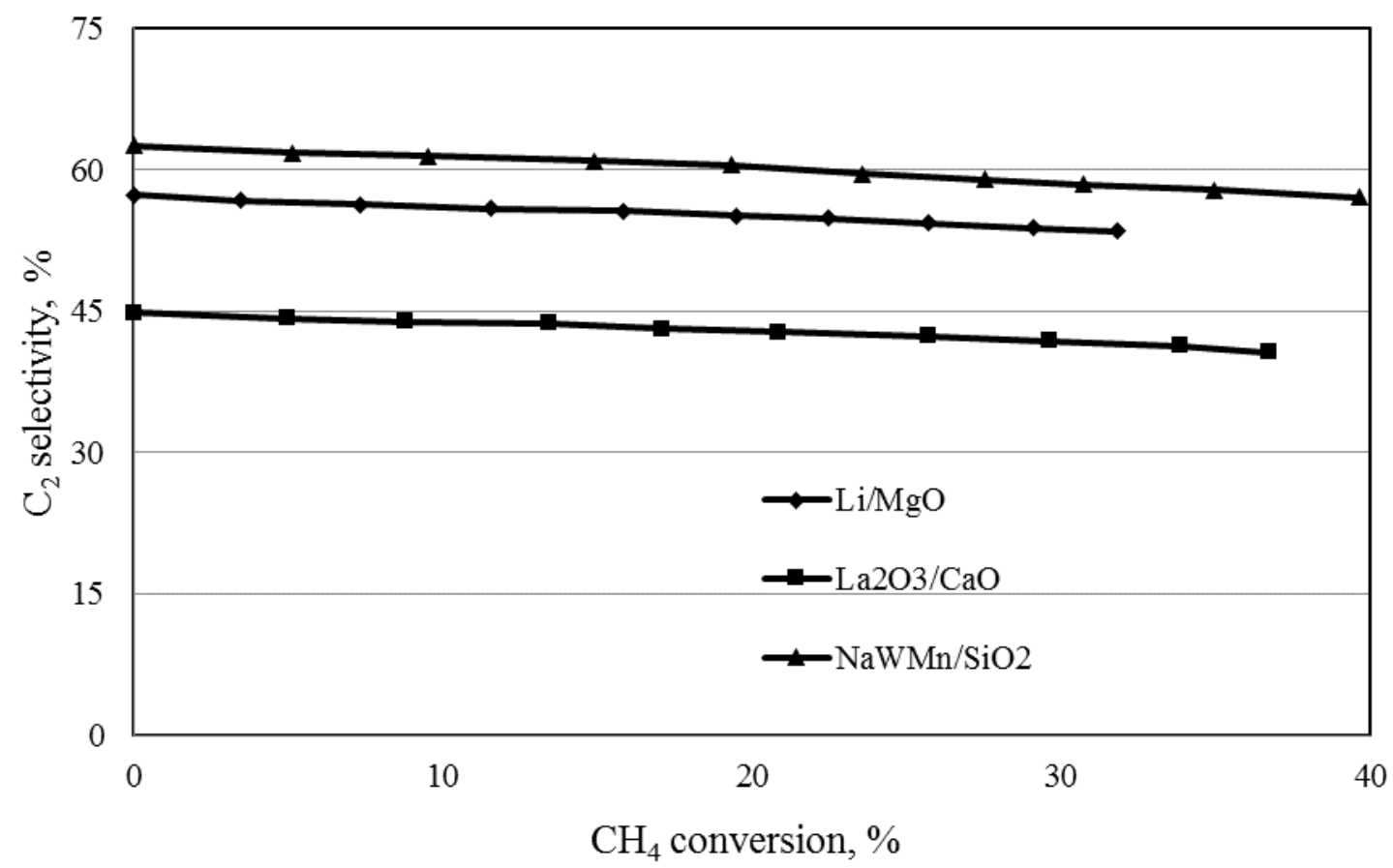

Fig. 7. $\mathrm{CH}_{4}$ conversion VS $\mathrm{C}_{2}$ selectivity $\left(\mathrm{T}=1073 \mathrm{~K}, \mathrm{CH}_{4} / \mathrm{O}_{2}\right.$ ratio $\left.=3.4\right)$. 


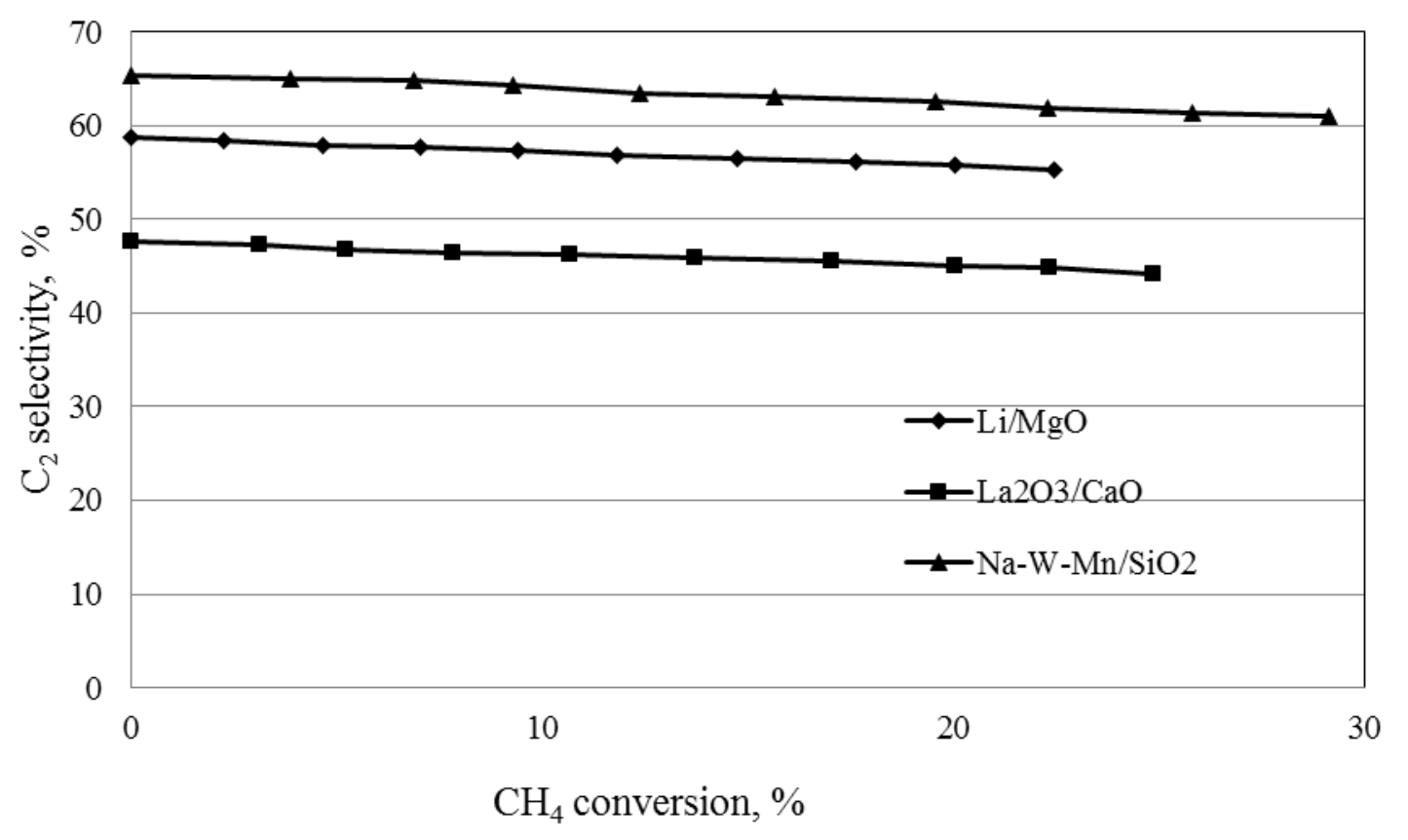

Fig. 8. $\mathrm{CH}_{4}$ conversion VS $\mathrm{C}_{2}$ selectivity $\left(\mathrm{T}=993 \mathrm{~K}, \mathrm{CH}_{4} / \mathrm{O}_{2}\right.$ ratio $\left.=3.4\right)$.

\subsection{Fixed Bed Reactor Study}

From the previous section, we know that the $\mathrm{Na}-\mathrm{W}-\mathrm{Mn} / \mathrm{SiO}_{2}$ catalyst exhibits the best performance for the OCM reaction. In the present study, the $\mathrm{Na}-\mathrm{W}-\mathrm{Mn} / \mathrm{SiO}_{2}$ catalyst was selected for this study. The effect of operating conditions, i.e., GHSV, temperature, $\mathrm{CH}_{4} / \mathrm{O}_{2}$ ratio and air flow rate, was investigated in a fixed bed reactor under non-isothermal mode. The 2-dimensional model was used to explore the profiles of temperature and concentration in the axial and radial directions.

\subsubsection{Effect of GHSV}

The effect of GHSV in a range of 9000 to $330001 / \mathrm{h}$, at a $\mathrm{CH}_{4} / \mathrm{O}_{2}$ ratio of 2 and at a temperature of 1073 $\mathrm{K}$ on the $\mathrm{CH}_{4}$ conversion and the $\mathrm{C}_{2}$ selectivity is presented in Fig. 9. The $\mathrm{CH}_{4}$ conversion decreased, whereas the $\mathrm{C}_{2}$ selectivity increased with the increase of the GHSV. Increasing the GHSV results in a lower contact time and hence, the $\mathrm{CH}_{4}$ and $\mathrm{O}_{2}$ conversions were decreased (Fig. 10 for $\mathrm{O}_{2}$ conversion). However, the higher GHSV was more favourable for the $\mathrm{C}_{2}$ hydrocarbon production because the shortening of the contact time between the $\mathrm{C}_{2}$ products with the oxygen can limit the formation of carbon oxides.

Figure 11 shows the ethylene concentration profile. The GHSV was considered at 9720 (a.), 16197.3 (b.), 25915.7 (c.) and 32394.6 (d.) $1 / \mathrm{h}$, and the temperature and $\mathrm{CH}_{4} / \mathrm{O}_{2}$ were fixed at 1073 and 2, respectively. From Figs. 11a - 11b, the amount of ethylene was decreased in the middle of a reactor because it reacts with oxygen to form carbon oxides. However, when the GHSV increases, the observed decrease in the amount of ethylene was reduced, as shown in Figs. 11(b)-(d). Figure 12 shows the temperature profile under this condition. For the lower GHSV results (a. and b), dissipation of the hot spot along the axis of the reactor was observed because the OCM reaction and the oxidation of hydrocarbons was highly exothermic. The reactor temperature increases as the reaction heat was accumulated. In this study, the hot spot disappears when operating at high GHSV, as shown in Figs. 12(c)-(d). All of the results indicate that the GHSV has significant influences on both the OCM performance and the thermal management of the reactors. 


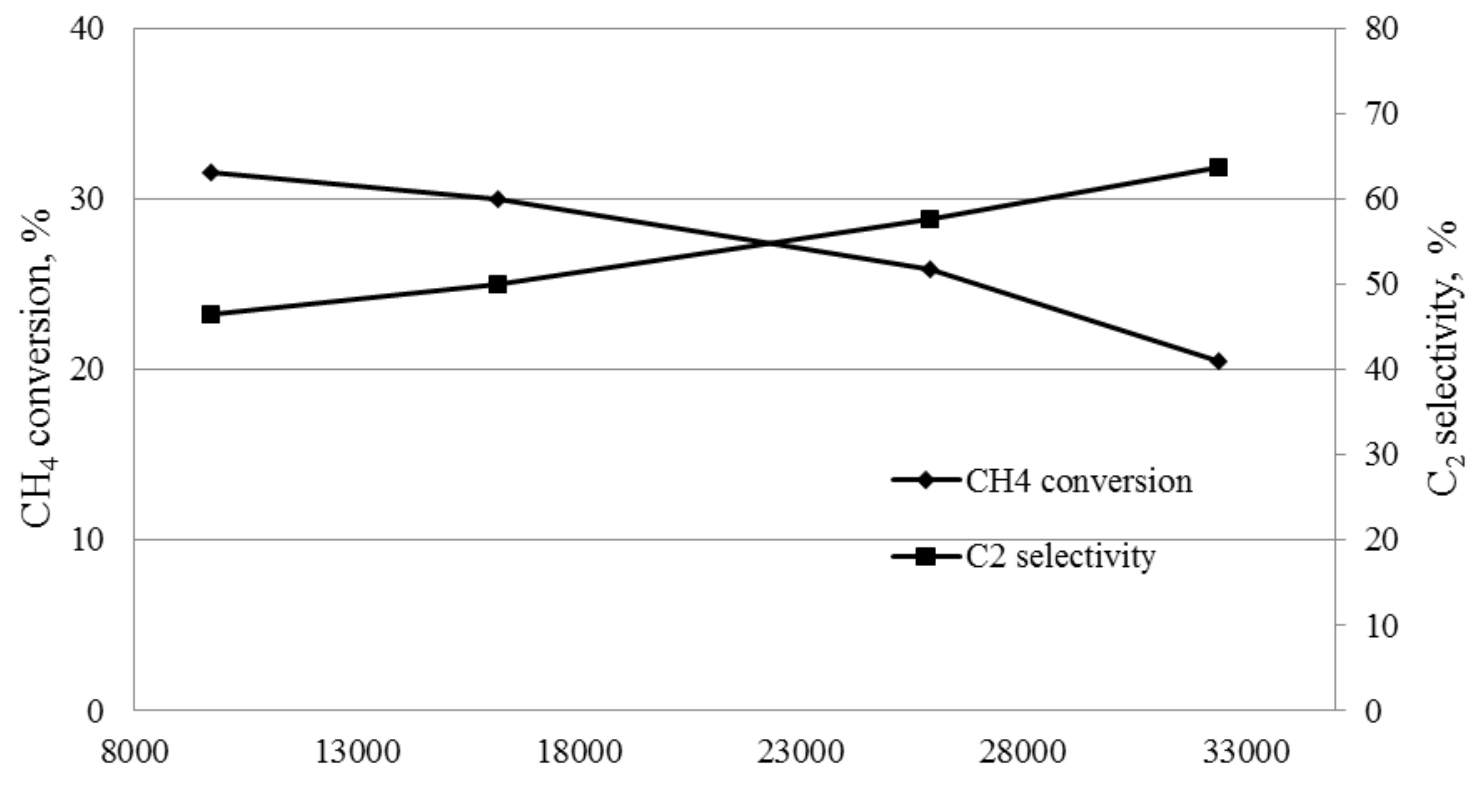

GHSV, 1/h

Fig. 9. Effect of GHSV on $\mathrm{CH}_{4}$ conversion and $\mathrm{C}_{2}$ selectivity.

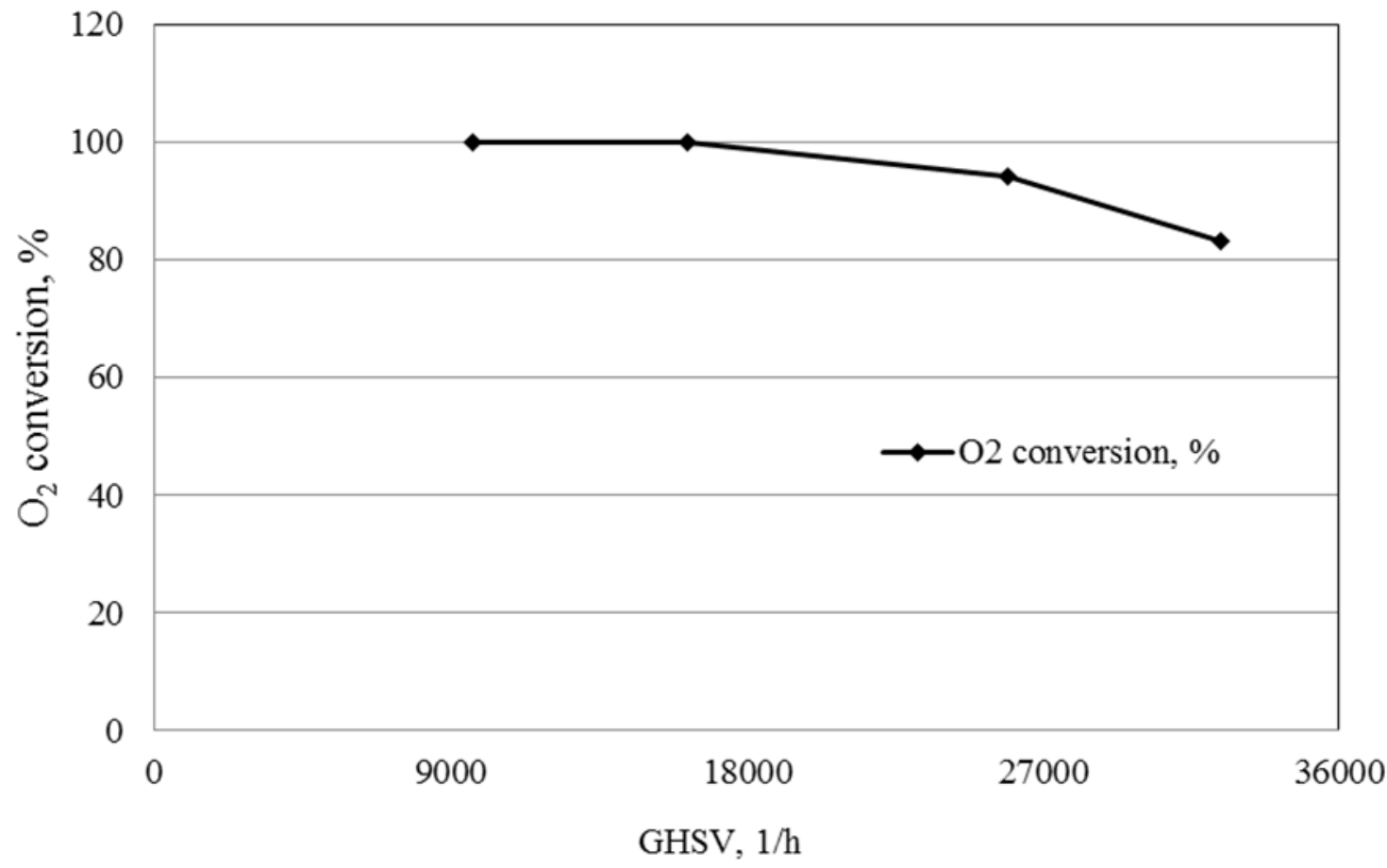

Fig. 10. Effect of GHSV on $\mathrm{O}_{2}$ conversion. 


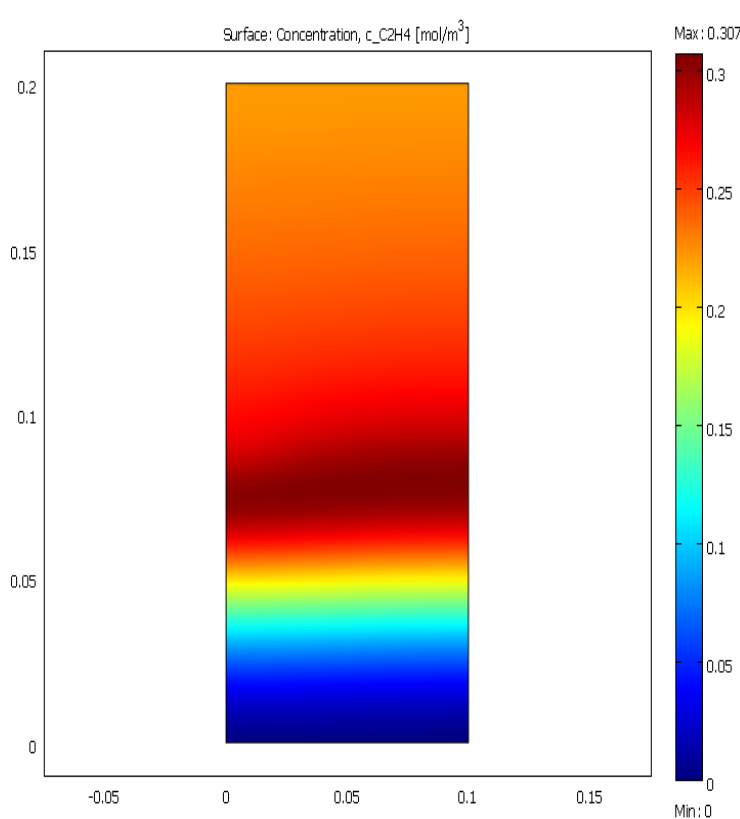

(a)

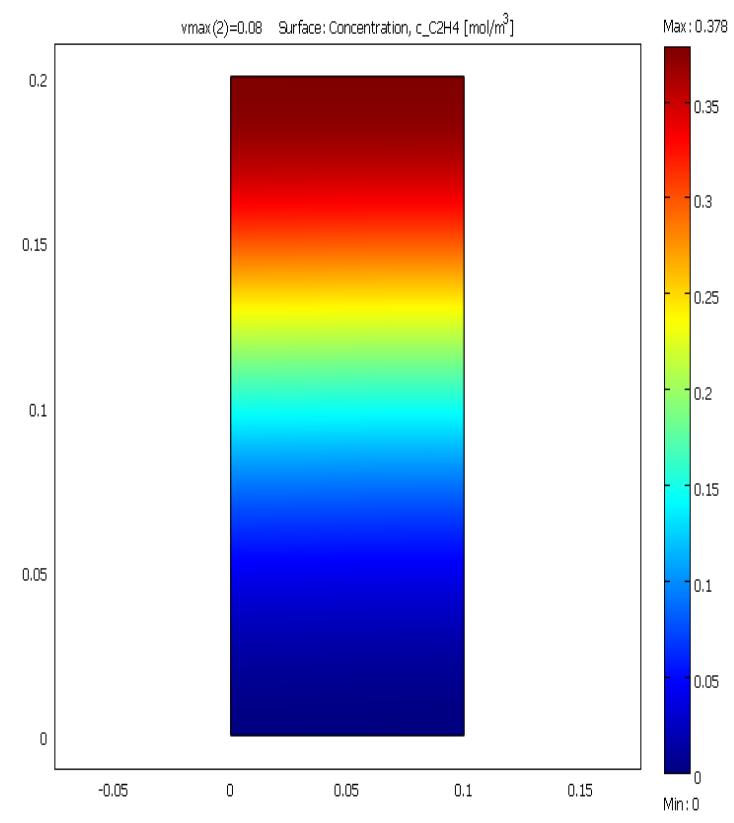

(c)

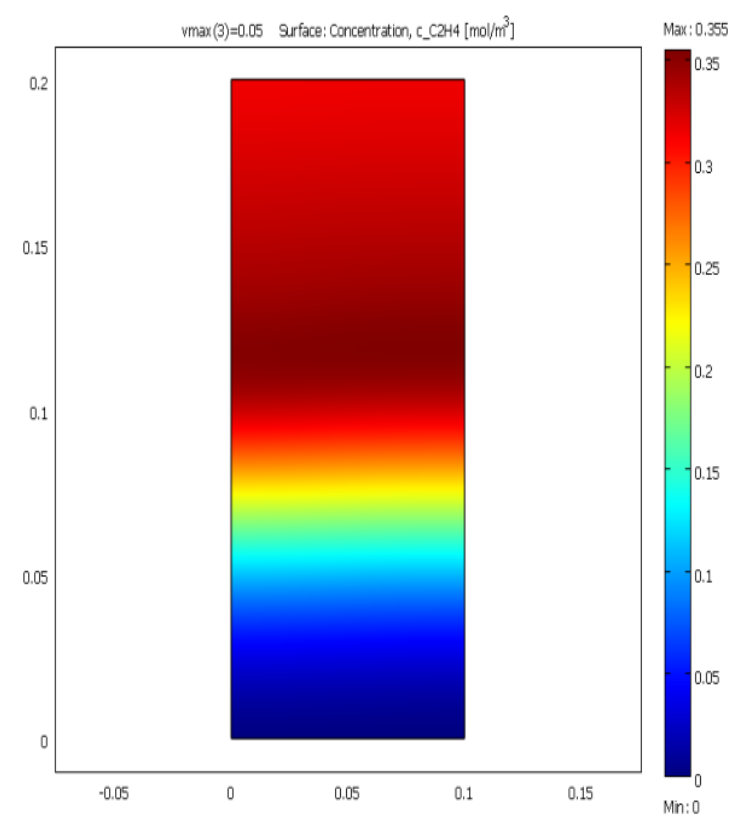

(b)

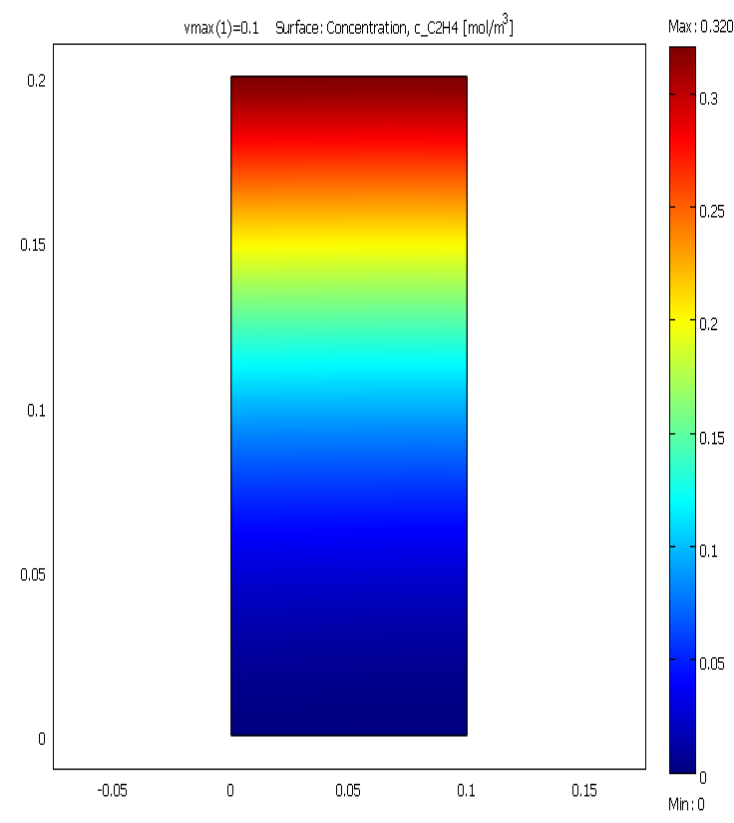

(d)

Fig. 11. Effect of GHSV on ethylene concentration profile at 9720 (a.), 16197.3 (b.), 25915.7 (c.) and 32394.6 (d.) $1 / \mathrm{h}\left(\mathrm{CH}_{4} / \mathrm{O}_{2}=2, \mathrm{~T}=1073 \mathrm{~K}\right)$. 


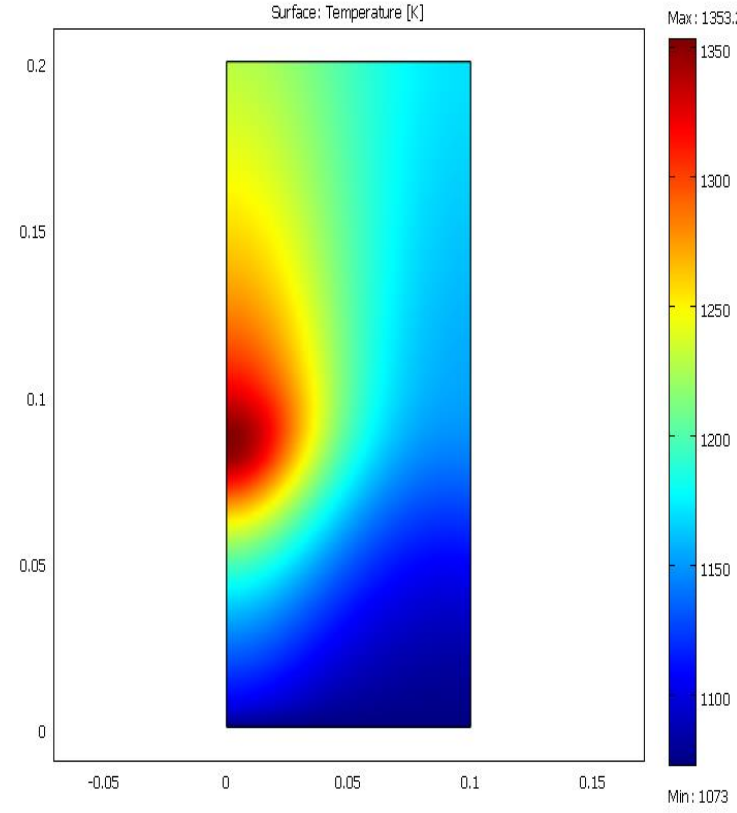

(a)

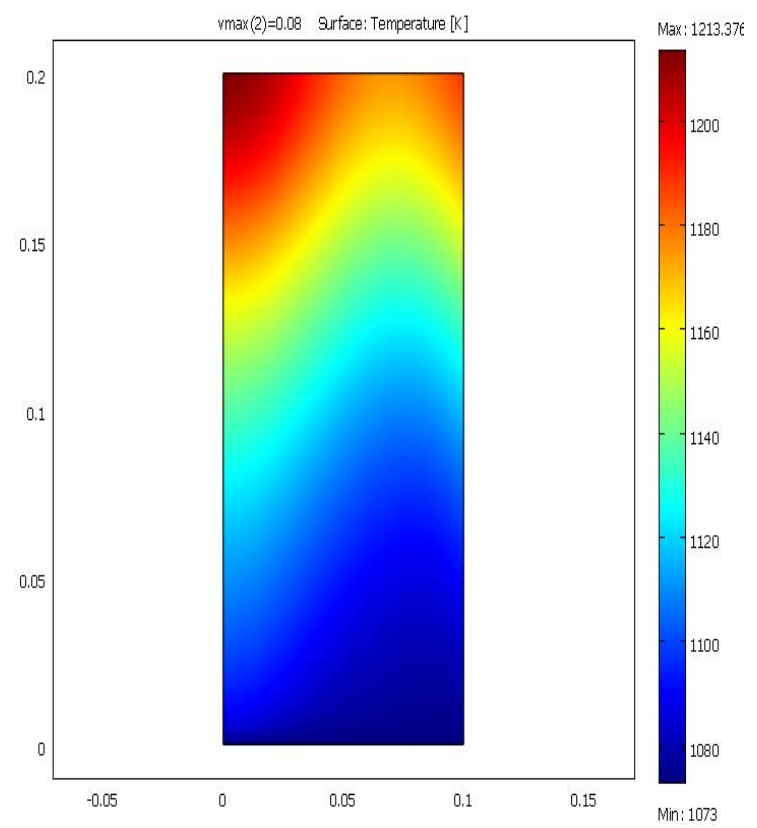

(c)

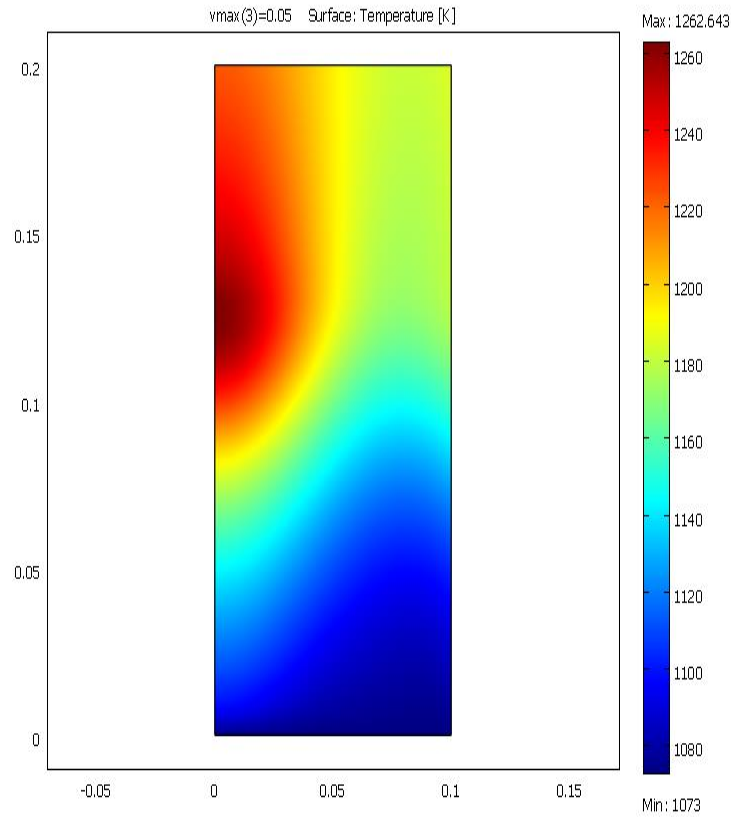

(b)

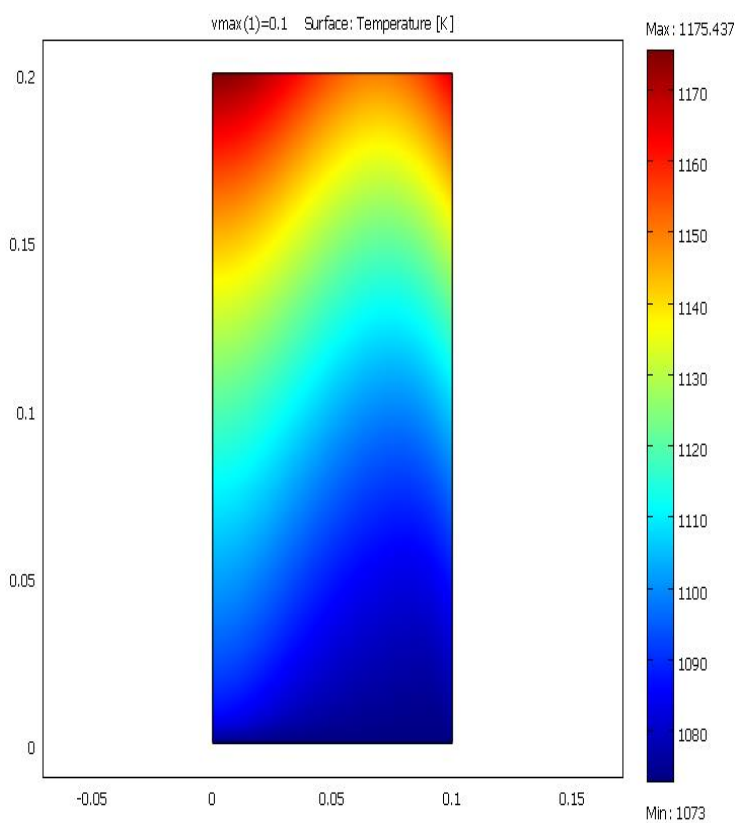

(d)

Fig. 12. Effect of GHSV temperature profile (a.), 16197.3 (b.), 25915.7 (c.) and 32394.6 (d.) $\left(\mathrm{CH}_{4} / \mathrm{O}_{2}=2\right.$, $T=1073 \mathrm{~K})$.

\subsubsection{Effect of temperature}

The effect of temperature on the $\mathrm{CH}_{4}$ conversion and the $\mathrm{C}_{2}$ selectivity is presented in Fig. 13 . The temperature was considered in a range of 993-1173 $\mathrm{K}$, the $\mathrm{CH}_{4} / \mathrm{O}_{2}$ ratio was 2 and the GHSV was 9720 $1 / \mathrm{h}$. It was found that when increasing the feed temperature, the $\mathrm{CH}_{4}$ conversion and the $\mathrm{CO}_{\mathrm{x}}$ selectivity were increased, thus decreasing the $\mathrm{C}_{2}$ selectivity. Hence, too high or too low a temperature was not beneficial for the $C_{2}$ yield. From the result, the best feed temperature would be $1073 \mathrm{~K}$ that represents highest $\mathrm{C}_{2}$ yields.

Figure 14 shows the temperature profile of the feed temperature at 993 (a.), 1023 (b.), 1073 (c.) and 1123(d.) $\mathrm{K}$, when the $\mathrm{CH}_{4} / \mathrm{O}_{2}$ ratio was 2 and the GHSV was $97201 / \mathrm{h}$. When increasing the feed 
temperature, the maximum temperature was found to increase as well. For the maximum temperature of up to $1543.7 \mathrm{~K}$, the inlet temperature was $1123 \mathrm{~K}$. The heat of reaction released in the OCM increased with the reaction temperature along the reactor. The higher temperature profiles for $1073 \mathrm{~K}$ and $1123 \mathrm{~K}$ indicate a hot spot occurring along the axis of the reactor. The temperature variation in the radial direction in the same plane lies in the range of 100 to $150 \mathrm{~K}$; hence, safety is a factor that should be considered. The wall temperature was an important parameter, which was related to the heat removal.

These results suggest finding an optimum condition to obtain the best system in this FBR study.

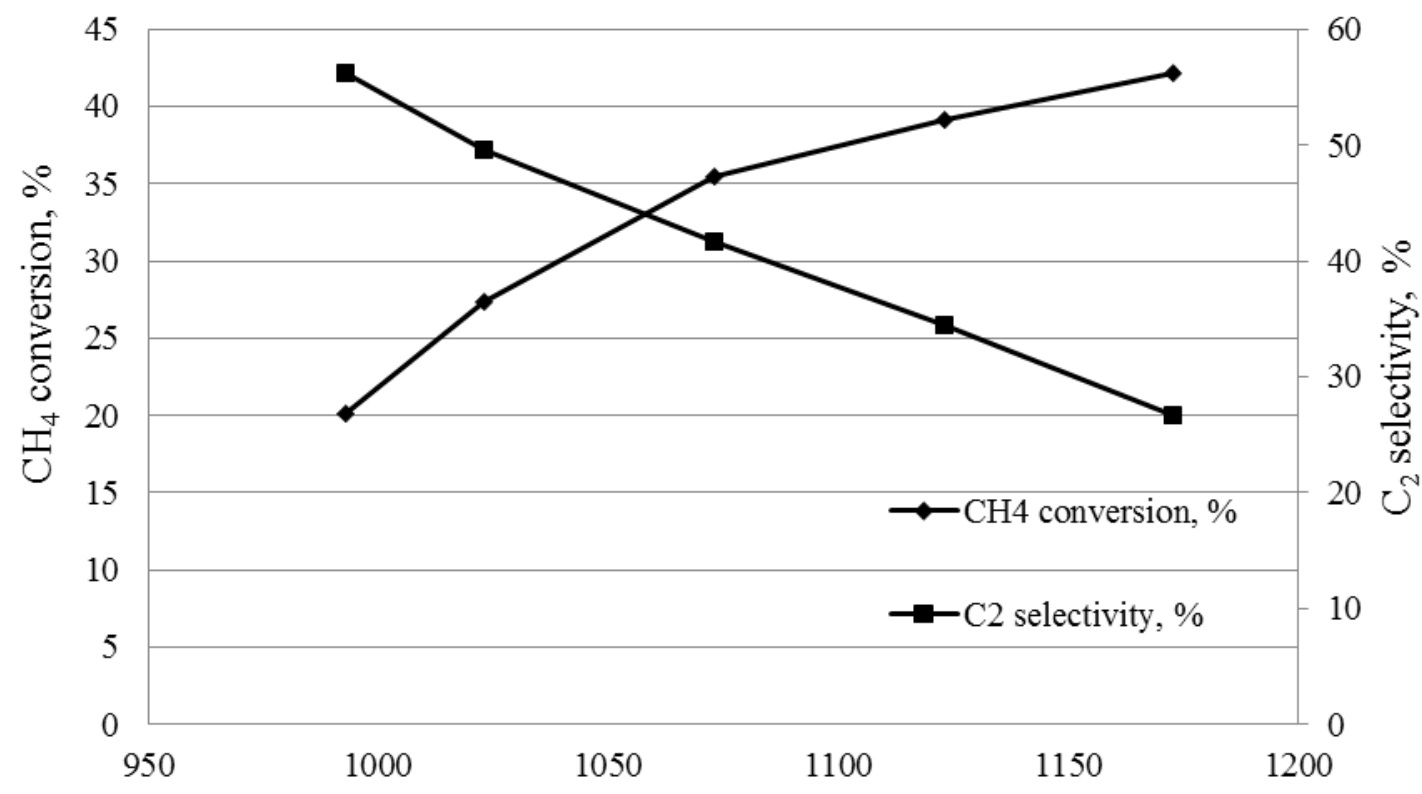

temperatre, $\mathrm{K}$

Fig. 13. Effect temperatures on $\mathrm{CH}_{4}$ conversion and $\mathrm{C}_{2}$ selectivity.

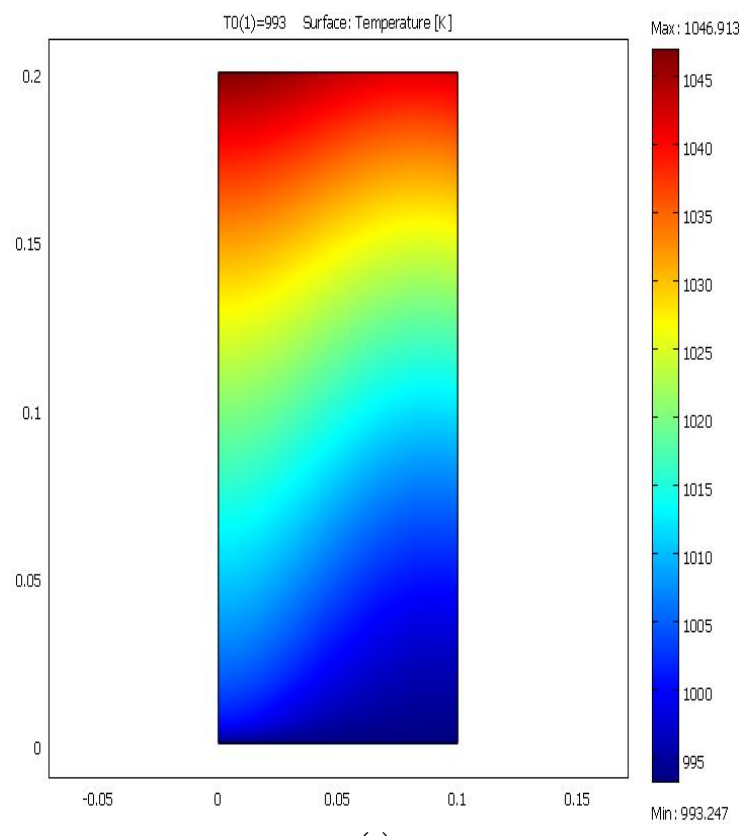

(a)

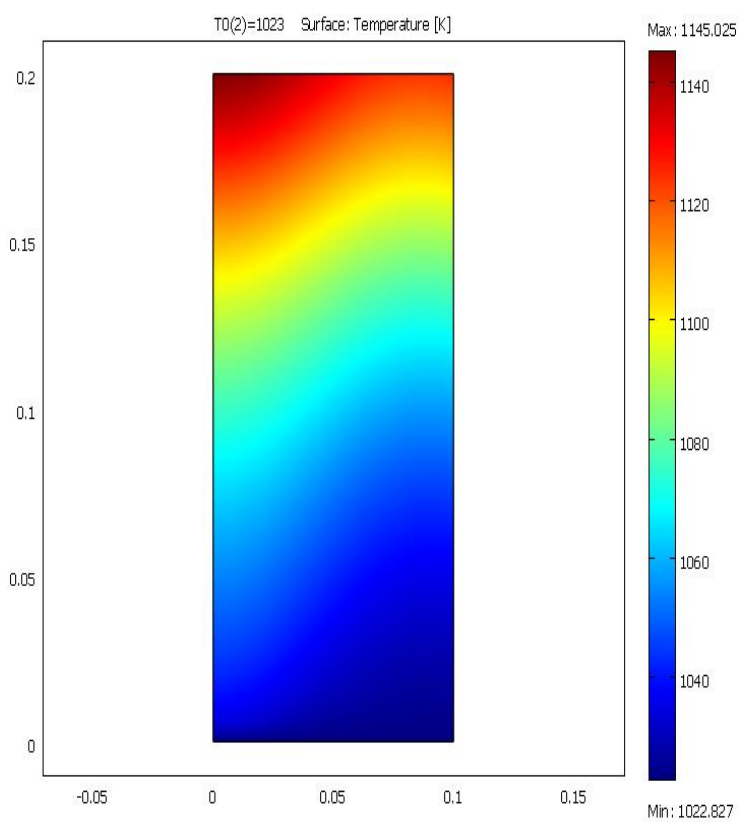

(b) 


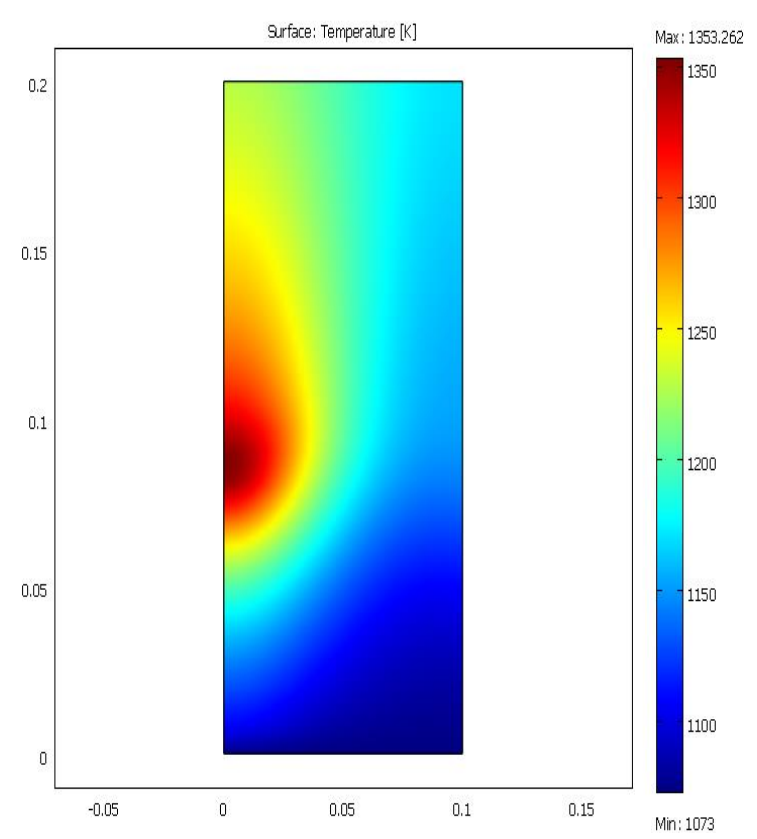

(c)

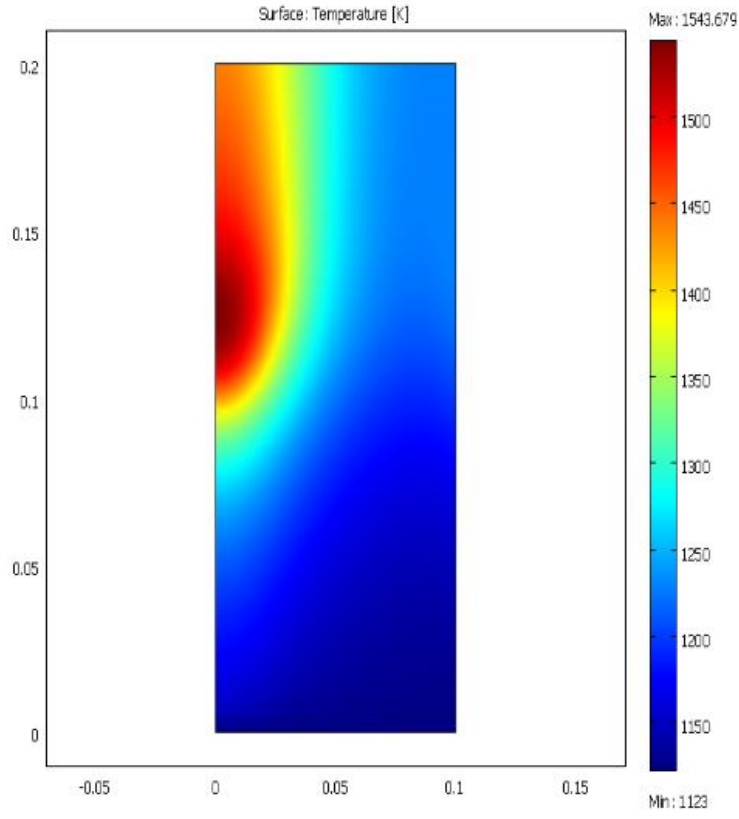

(d)

Fig.14. Temperature profile at $T=993$ (a.), 1023 (b.), 1073 (c.) and 1123 (d.) $\mathrm{K}\left(\mathrm{CH}_{4} / \mathrm{O}_{2}=2\right.$, GHSV = $97201 /$ h).

\subsubsection{Effect of $\mathrm{CH}_{4} / \mathrm{O}_{2}$ ratio}

The effect of the $\mathrm{CH}_{4} / \mathrm{O}_{2}$ ratio in a range 2-7.5 at a GHSV of $97201 / \mathrm{h}$ and a temperature of $1073 \mathrm{~K}$ on the $\mathrm{CH}_{4}$ conversion and the $\mathrm{C}_{2}$ selectivity is presented in Fig. 15. The $\mathrm{CH}_{4}$ conversion was decreased, whereas the $\mathrm{C}_{2}$ selectivity was increased with the increase of the $\mathrm{CH}_{4} / \mathrm{O}_{2}$ ratio. The oxygen also causes the production of methyl radicals which cause the formation of $\mathrm{C}_{2}$ hydrocarbons. Because the oxygen content in feed was decreased to cause an insufficient amount of oxygen in the reaction, the $\mathrm{CH}_{4}$ conversion was decreased. However, when the oxygen concentration was high (low $\mathrm{CH}_{4} / \mathrm{O}_{2}$ ratio) the oxidation of methane and the $\mathrm{C}_{2}$ product became pronounced. Figure 16 shows the oxygen and ethylene concentrations at $\mathrm{CH}_{4} / \mathrm{O}_{2}$ ratios of 2 and 3.4 in Figs. 16(a) and 16(b), respectively, to provide a comparison on the OCM performance. At a $\mathrm{CH}_{4} / \mathrm{O}_{2}$ ratio of 2, Fig. 16(a1) shows the $\mathrm{O}_{2}$ conversion was $100 \%$ at the first part of the reactor and that the $\mathrm{CH}_{4}$ conversion was as high as $55.83 \%$. In addition, Fig. 16(a2) shows that the ethylene concentration starts to decrease at same point of $100 \%$ conversion of oxygen because it was oxidized to $\mathrm{CO}_{\mathrm{x}}$. The ethylene concentration was improved with increasing $\mathrm{CH}_{4} / \mathrm{O}_{2}$ ratio to 3.4, as shown in Fig. 16(b). In addition, the effect of the $\mathrm{CH}_{4} / \mathrm{O}_{2}$ ratio has an influence on the temperature in the reactor. Figure 17 shows the temperature profile at $\mathrm{CH}_{4} / \mathrm{O}_{2}$ ratios of 2 (a.) and 3.4 (b.). The hot spot disappeared when the $\mathrm{CH}_{4} / \mathrm{O}_{2}$ ratio was 3.4 because the reaction site is extended along the inner wall thus reaction is faster with higher selectivity and yield, at the same time reducing the hot spot existing in catalyst. 


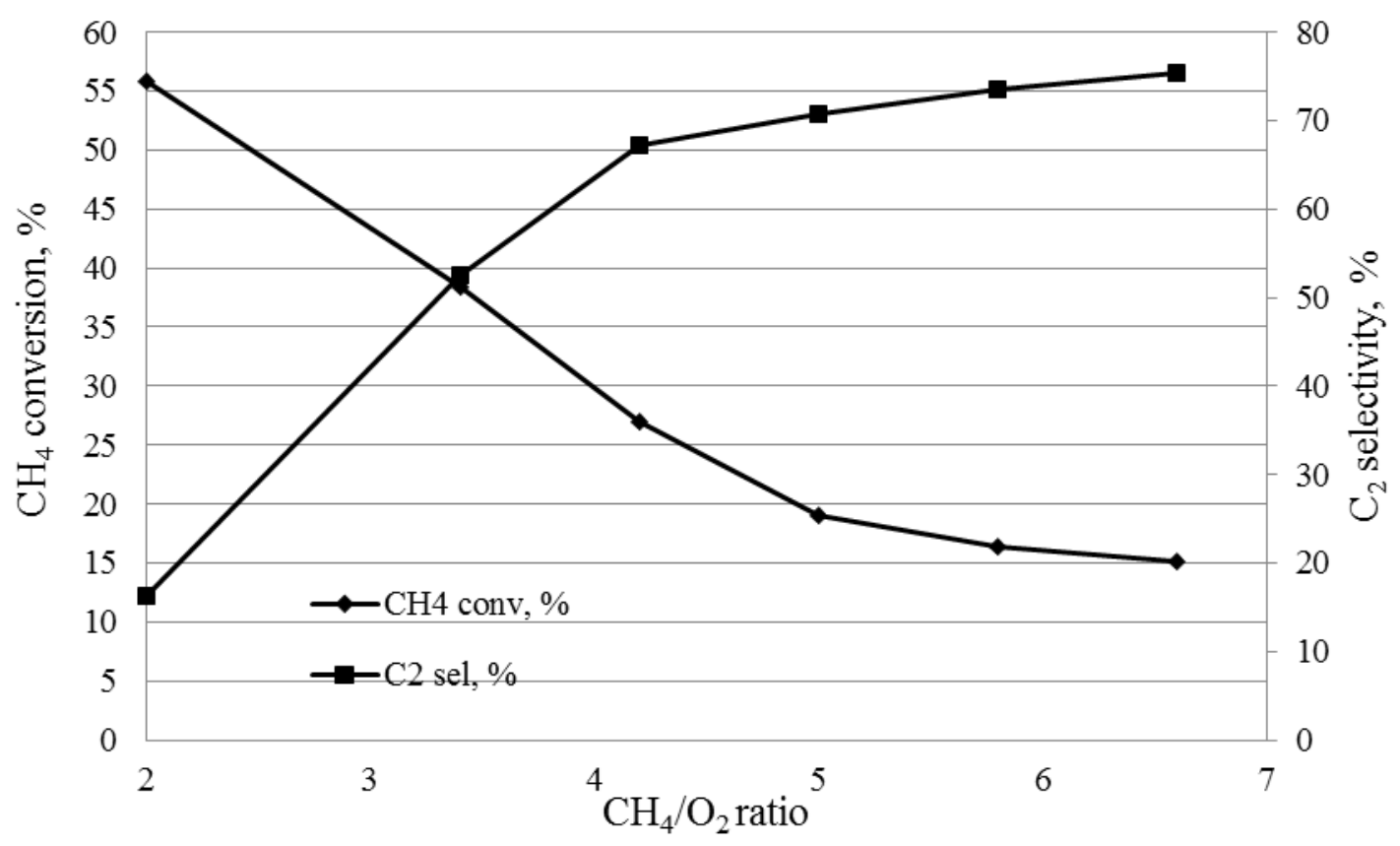

Fig. 15. Effect $\mathrm{CH}_{4} / \mathrm{O}_{2}$ ratio on $\mathrm{CH}_{4}$ conversion and $\mathrm{C}_{2}$ selectivity.

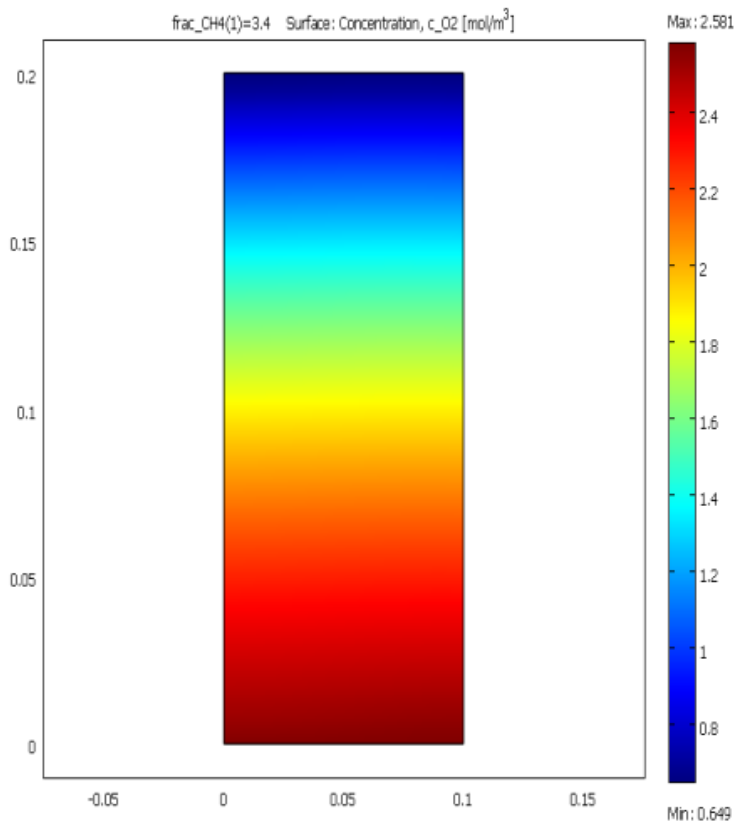

(a1)

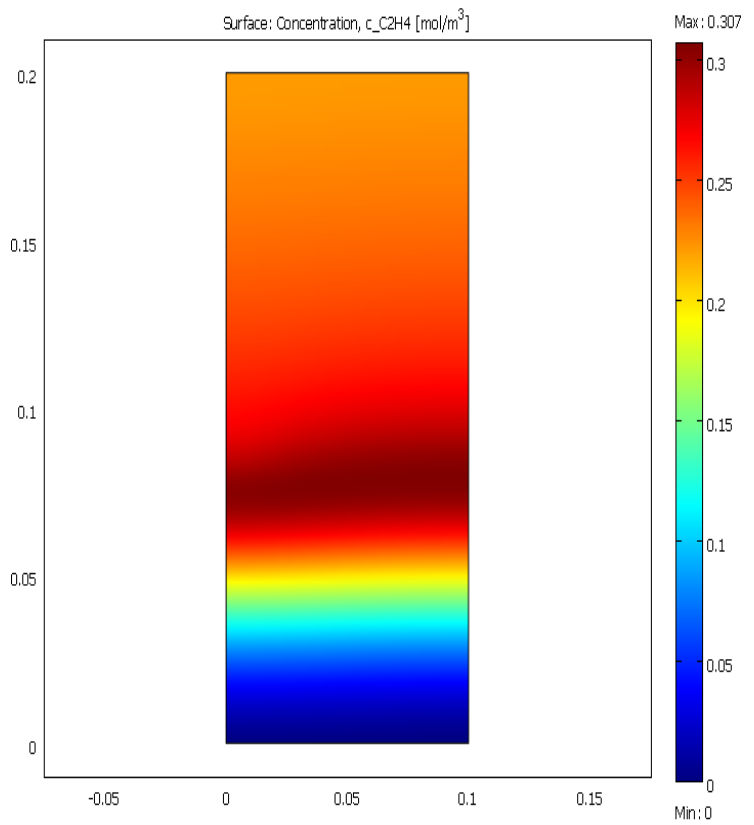

(a2) 


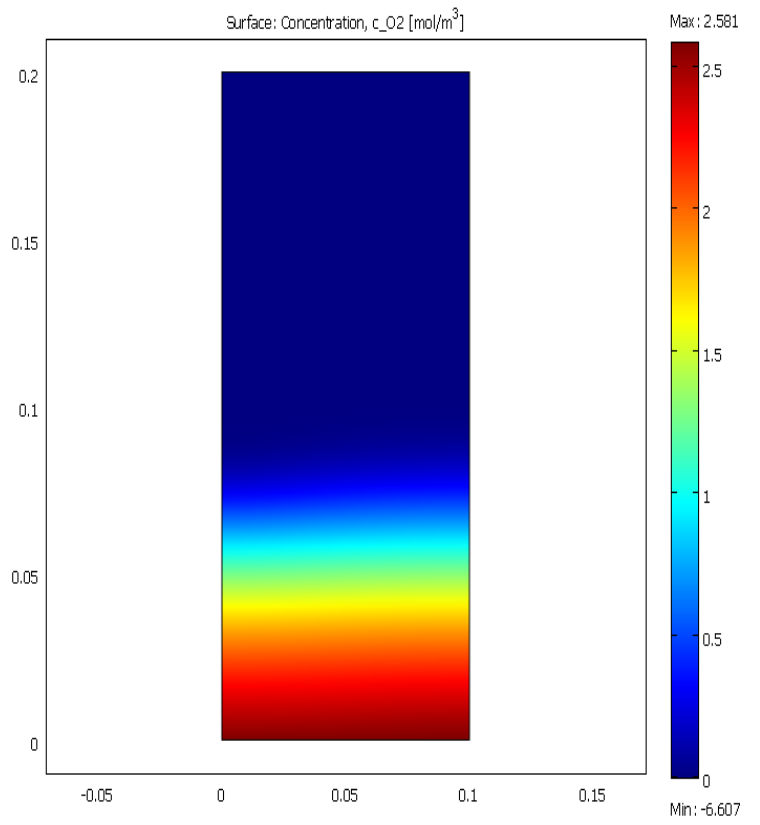

(b1)

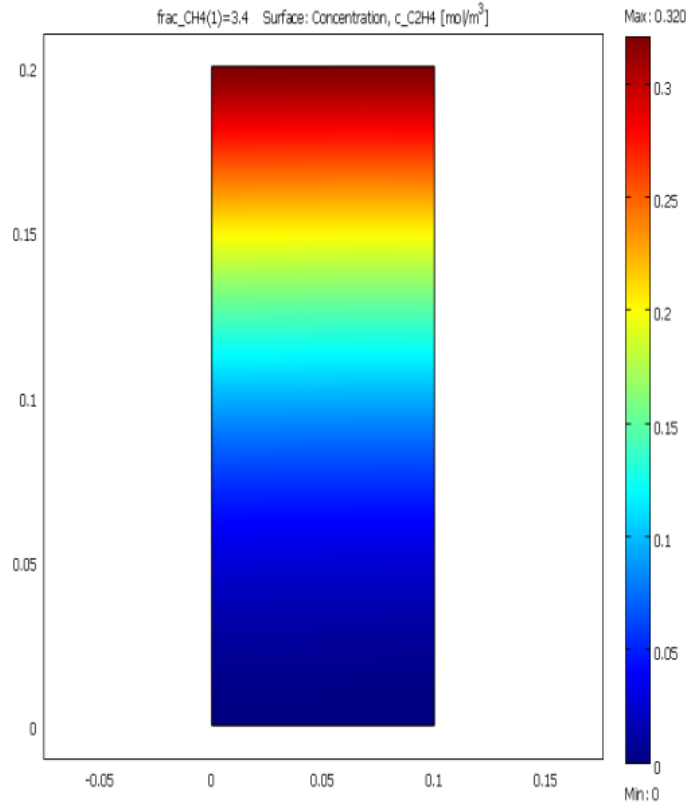

(b2)

Fig. 16. Effect of $\mathrm{CH}_{4} / \mathrm{O}_{2}$ ratio on concentration profile a. $\mathrm{CH}_{4}: \mathrm{O}_{2}=2, \mathrm{~T}=1073 \mathrm{~K}$, GHSV $=9720$ 1/h b. $\mathrm{CH}_{4}: \mathrm{O}_{2}=3.4, \mathrm{~T}=1073 \mathrm{~K}, \mathrm{GHSV}=97201 / \mathrm{h}$.

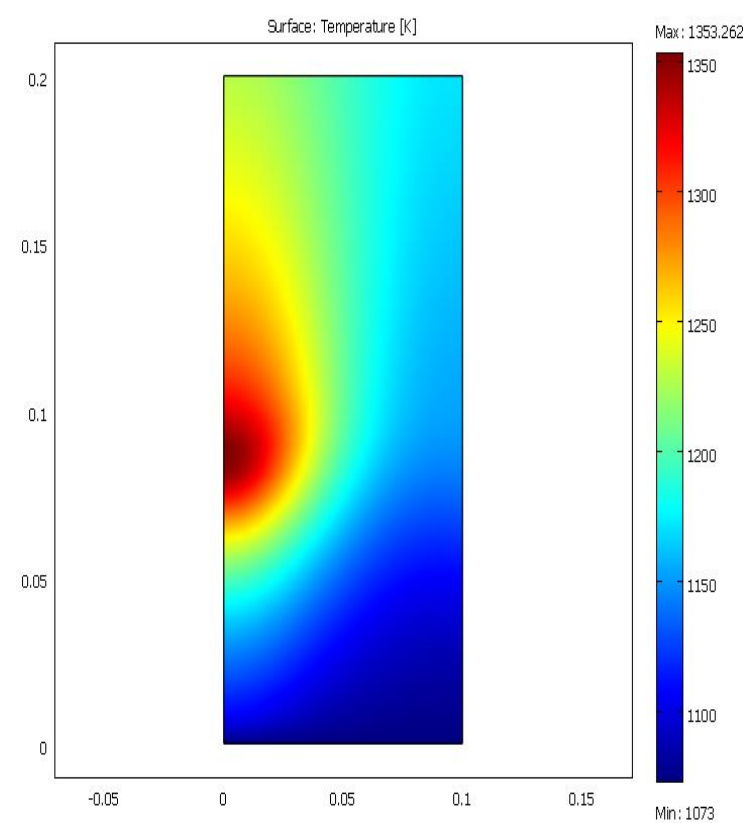

(a)

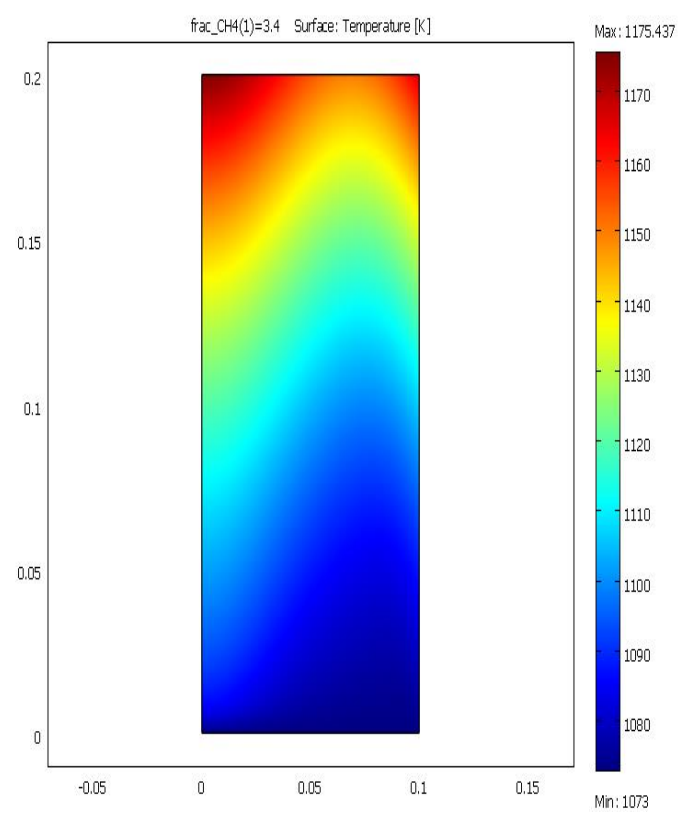

(b)

Fig. 17. Effect of $\mathrm{CH}_{4} / \mathrm{O}_{2}$ ratio on temperature profile a. $\mathrm{CH}_{4}: \mathrm{O}_{2}=2, \mathrm{~T}=1073 \mathrm{~K}$, GHSV $=9720$ 1/h b. $\mathrm{CH}_{4}: \mathrm{O}_{2}=3.4, T=1073 \mathrm{~K}, \mathrm{GHSV}=97201 / \mathrm{h}$.

\subsection{Effect of the Mode of Operation}

It was interesting to compare the effect of the mode of operation, including isothermal, adiabatic and nonisothermal conditions, on the $\mathrm{CH}_{4}$ conversion, the $\mathrm{C}_{2}$ selectivity and the $\mathrm{C}_{2}$ yield. Table 6 presents the results of the comparison under the same feed conditions. The OCM process was simulated under 
conditions of a $\mathrm{CH}_{4} / \mathrm{O}_{2}$ ratio of 3.4 , a feed temperature of $1073 \mathrm{~K}$ and a GHSV of $9720 \mathrm{1} / \mathrm{h}$. When comparing the different modes, the $\mathrm{CH}_{4}$ conversion in adiabatic mode was higher than those of the nonisothermal mode and isothermal mode, but it exhibited the least $\mathrm{C}_{2}$ selectivity. Moreover, operation in adiabatic mode exhibits a hot spot (region) along the axis of the reactor, as seen from the temperature profile in Fig. 18(a). To limit the hot spot, providing some arrangement of cooling around the catalyst bed can control the temperature in the reaction, as demonstrated in the case of the non-isothermal operation mode shown in Fig. 18(b). Other methods were proposed to solve the hot spot problem, such as shortening the catalyst bed or dilution of the first portion of the catalyst bed (Moustafa et al. (2007)). The $\mathrm{C}_{2}$ yield of $20.16 \%$ was achieved in non-isothermal mode, while they were $20.00 \%$ and $17.62 \%$ for isothermal and adiabatic modes, respectively. The nature of the OCM reaction was highly exothermic. Hence, to achieve this operation condition, a cooling temperature with a high heat transfer coefficient was required.

Table 6. OCM performance at different mode operation.

\begin{tabular}{lccc}
\hline Performance & isothermal & adiabatic & Non-isothermal \\
\hline $\mathrm{CH}_{4}$ Conversion, \% & 36.14 & 42.27. & 38.43 \\
$\mathrm{C}_{2}$ Selectivity, \% & 55.35 & 41.68 & 52.46 \\
$\mathrm{C}_{2}$ Yield, $\%$ & 20.00 & 17.62 & 20.16 \\
\hline
\end{tabular}

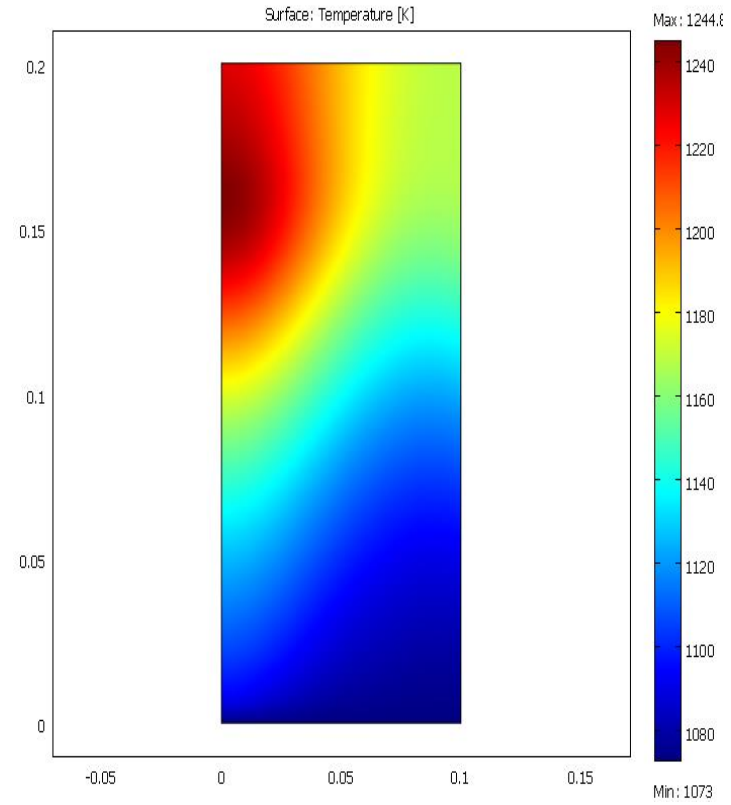

(a)

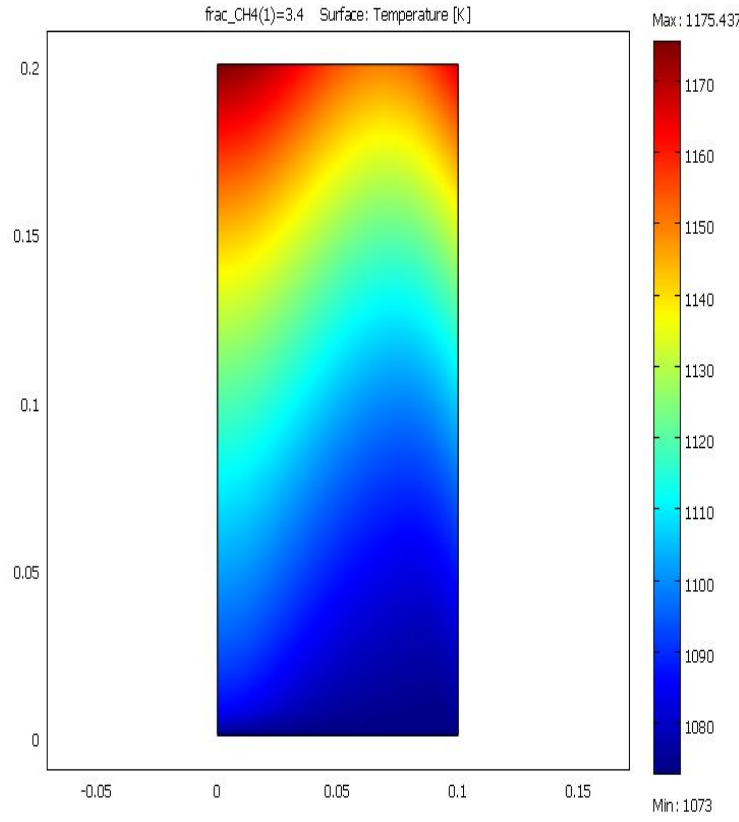

(b)

Fig. 18. Effect of mode of operation on temperature profile a. adiabatic mode b. non-isothermal mode $\left(\mathrm{CH}_{4}: \mathrm{O}_{2}=3.4, \mathrm{~T}=1073 \mathrm{~K}, \mathrm{GHSV}=97201 / \mathrm{h}\right)$.

The 2-dimensional model studied and analyzed the effect of operating variables such as $\mathrm{CH}_{4} / \mathrm{O}_{2}$ ratio, GHSV and temperature in the fixed bed reactor on the reaction performances such as conversion, selectivity, yield via expression of surface plot for each profile (concentration and temperature profiles). The comparison of these results and Karimi et al.,2007 supported that the operating condition particularly temperature, GHSV and the $\mathrm{CH}_{4} / \mathrm{O}_{2}$ ratio was strongly effect the OCM reaction on $\mathrm{C}_{2}+$ selectivity, $\mathrm{CH}_{4}$ conversion and the yield of $\mathrm{C}_{2}$ However the detailed $2 \mathrm{D}$ model can provide more accurate predictions of experimental data than the simplified one. 


\section{Conclusions}

Two-dimensional mathematical modeling of the oxidative coupling of methane (OCM) in a fixed bed reactor was studied in this research. The simulations were performed using the Comsol multiphysics program. The present study indicated that the models were well-validated with the previous results reported in the literature. Suitable catalysts were selected via a comparison among the $\mathrm{Na}-\mathrm{W}-\mathrm{Mn} / \mathrm{SiO}_{2}, \mathrm{La}_{2} \mathrm{O}_{3} / \mathrm{CaO}$ and $\mathrm{Li} / \mathrm{MgO}$ catalysts in isothermal mode. The simulation results indicated that the $\mathrm{Na}-\mathrm{W}-\mathrm{Mn} / \mathrm{SiO}_{2}$ catalyst offers the best performances among all of the catalysts under various conditions. Different operating conditions, such as temperature, $\mathrm{CH}_{4} / \mathrm{O}_{2}$ ratio and GHSV, influence the performance of the OCM reactors packed with $\mathrm{Na}-\mathrm{W}-\mathrm{Mn} / \mathrm{SiO}_{2}$ and operated in non-isothermal mode. Increasing the operating temperature increased the $\mathrm{CH}_{4}$ conversion but decreased the $\mathrm{C}_{2}$ selectivity However, the effects of $\mathrm{CH}_{4} / \mathrm{O}_{2}$ ratio and GHSV exhibited contrary results. Especially regarding the hot spots in the reactor, it was found that the three operating variables $\left(\mathrm{CH}_{4} / \mathrm{O}_{2}\right.$ ratio, GHSV and temperature) affect the occurrence of hot spots. A suitable condition to achieve the best performance was at a $\mathrm{CH}_{4} / \mathrm{O}_{2}$ ratio of 3.4, a feed temperature of $1073 \mathrm{~K}$ and a GHSV of 9720 1/h. The maximum $\mathrm{C}_{2}$ yield was $20.16 \%$. In addition, from the studies of the three modes, isothermal, adiabatic and non-isothermal, the results were found for the non-isothermal and isothermal modes; heat management can improve the performance of the OCM reactor, which can be used in a real operation in the reactor design. Moreover, the performance of the OCM may be improved when changing the reactor configuration, e.g., a catalytic membrane reactor should be considered.

\section{Acknowledgements}

The authors gratefully acknowledge the Thailand Research Fund (DPG5880003) for the financial support.

\section{References}

[1] J. H. Lunsford, "Catalytic conversion of methane to more useful chemical and fuel: A challenge for the 21st century," Catalysis Today, vol. 63, pp. 165-174, 2000.

[2] G. E. Keller and M. M. Bhasin, "Synthesis of ethylene via oxidative coupling of methane. I. Determination of active catalysts," Journal of Catalysis, vol. 73, pp. 9-19, 1982.

[3] W. Wang and Y. S. Lin, "Analysis of oxidative coupling of methane in dense oxide membrane reactors," Journal of Membrane Science, vol. 103, pp. 219-233, 1995.

[4] Z. Stansch, L. Mleczko, and M. Baerns, "Comprehensive kinetics of oxidative coupling of methane over the $\mathrm{La}_{2} \mathrm{O}_{3} / \mathrm{CaO}$ catalyst," Industrial \& Engineering Chemistry Research, vol. 36, pp. 2568-2579, 1997.

[5] S. Lacombe, Z. Durjanova, L. Mleczko, and C. Mirodatos, "Kinetic modeling of the oxidative coupling of methane over lanthanum oxide in connection with mechanistic studies," Chemical Engineering Technology, vol. 18, pp. 216-223, 1995.

[6] M. Traykovaa, N. Davidovaa, J. S. Tsaihb, and A. H. Weiss, "Oxidative coupling of methane the transition from reaction to transport control over $\mathrm{La}_{2} \mathrm{O}_{3} / \mathrm{MgO}$ catalyst," Applied Catalysis, vol. 169, pp. 237-247, 1998.

[7] M. K. S. Shahri and S. M. Alavi, "Kinetic studies of the oxidative coupling of methane over the $\mathrm{Mn} / \mathrm{Na}_{2} \mathrm{WO}_{4} / \mathrm{SiO}_{2}$ catalyst," Journal of Natural Gas Chemistry, vol. 18, pp. 25-34, 2009.

[8] S. Kus, M. Otrenba, and M. Taniewski, "The catalytic performance in oxidative coupling of methane and the surface basicity of $\mathrm{La}_{2} \mathrm{O}_{3}, \mathrm{Nd}_{2} \mathrm{O}_{3}, \mathrm{ZrO}_{2}$, and $\mathrm{Nb}_{2} \mathrm{O}_{5}$," Fuel, vol. 82, pp. 1331-1338, 2003.

[9] S. Pak, P. Qia, and J.H. Lunsford, "Elementary reactions in the Oxidative coupling of methane over $\mathrm{Na}_{2} \mathrm{WO}_{4}-\mathrm{Mn} / \mathrm{SiO}_{2}$ and $\mathrm{Na}_{2} \mathrm{WO}_{4}-\mathrm{Mn} / \mathrm{SiO}_{2}$," Journal of Catalysis, vol. 179, pp. 220-230, 1998.

[10] S. J. Li, "Reaction chemistry of $\mathrm{W}-\mathrm{Mn} / \mathrm{SiO}_{2}$ catalyst for the oxidative coupling of methane," Natural Gas Chemistry, vol. 12, pp. 1-9, 2003.

[11] H. Liu, X. Wang, D., Yung, R. Gao, Z. Wang, and J. Jung, "Scale up and stability test for oxidative coupling of methane over $\mathrm{Na}_{2} \mathrm{WO}_{4}-\mathrm{Mn} / \mathrm{SiO}_{2}$ catalyst in a $200 \mathrm{ml}$ fixed-bed reactor," Natural Gas Chemistry, vol. 17, pp. 59-63, 2008.

[12] C. T. Tye, A. R. Mohamed, and S. Bhatia, "Modeling of catalytic reactor for oxidative coupling of methane using $\mathrm{La}_{2} \mathrm{O}_{3} / \mathrm{CaO}$ catalyst," Chemical Engineering Journal, vol. 87, pp. 49-59, 2002. 
[13] Y. K. Kao, L. Lei, and Y. S. Lin, "A comparative simulation study on oxidative coupling of methane in fixed-bed and membrane reactors," Industrial \& Engineering Chemistry Research, vol. 36, pp. 3583-3593, 1997.

[14] J. H. Lunsford, "The catalytic coupling of methane," Angewandte Chemie International Edition in English, vol. 34, pp. 970-980, 2006.

[15] J. A. Langille, J. Pasaleb, J. Y. Renb, F. N. Egolfopoulosa, and T. T. Tsotsisb, "The use of OCM reactors for ignition enhancement of natural gas combustion for practical applications: Reactor design aspects," Chemical Engineering Science, vol. 61, pp. 6637-6645, 2006.

[16] N. A. S. Amin and S. E. Pheng, "Influence of process variables and optimization of ethylene yield in oxidative coupling of methane over $\mathrm{Li} / \mathrm{MgO}$ catalyst," Chemical Engineering Journal, vol. 116, pp. 187$195,2006$.

[17] L. Mleczko, U. Pannek, M. Rothaemel, and M. Baerns, "Oxidative coupling of methane over a $\mathrm{La}_{2} \mathrm{O}_{3} / \mathrm{CaO}$ catalyst. Optimization of reaction conditions in a bubbling fluidized-bed reactor," The Canadian Journal of Chemical Engineering, vol. 74, pp. 279-287, 1996.

[18] M. Daneshpayeh, K. Abbasali, M. Navid, M. Yadolah, S. Rahmate, and T. Alireza, "Kinetic modeling of oxidative coupling of methane over $\mathrm{Mn} / \mathrm{Na}_{2} \mathrm{WO}_{4} / \mathrm{SiO}_{2}$ catalyst," Fuel Processing Technology, vol. 90, pp. 403-410, 2009.

[19] S. Bhatia, C. Y. Thien, A. Rahman, "Oxidative coupling of methane (OCM) in a catalytic membrane reactor and comparison of its performance with other catalytic reactors," Chemical Engineering Journal, vol. 148, pp. 525-532, 2009.

[20] H. Wang, C. You, and W. Yung, "Oxidative coupling of methane in $\mathrm{Ba}_{0.5} \mathrm{Sr}_{0.5} \mathrm{Co}_{0.8} \mathrm{Fe}_{0.2} \mathrm{O}_{3-\delta}$ (BSCF) tubular membrane reactors," Catalysis Today, vol. 104, pp. 160-167, 2005.

[21] A. Karimi, R. Ahmadi, Z. Bozorg, J. Jebreili, and A. Barkhordarion, "Catalytic oxidative coupling of methane experimental investigation and optimization of operational condition," Petroleum \& Coal, vol. 49, pp. 36-40, 2007. 